Received 00th January 20xx, Accepted 00th January 20xx

DOI: $10.1039 / x 0 x \times 00000 x$

\title{
An Unsaturated Four-Coordinate Dimethyl Dimolybdenum Complex with a Molybdenum-Molybdenum Quadruple Bond
}

\author{
Natalia Curado, ${ }^{a}$ Mario Carrasco, ${ }^{a}$ Jesús Campos, ${ }^{a}$ Celia Maya, ${ }^{a}$ Amor Rodríguez, ${ }^{a}$ Eliseo Ruiz, \\ Santiago Álvarez ${ }^{\mathrm{b}}$ and Ernesto Carmona ${ }^{\mathrm{a}}$
}

\begin{abstract}
We describe the synthesis, molecular, and electronic structure of the complex $\left[\mathrm{Mo}_{2} \mathrm{Me}_{2}\left\{\mu-\mathrm{HC}(\mathrm{NDipp})_{2}\right\}_{2}\right](2)$, that contains a dimetallic core with a Mo-Mo quadruple bond and features uncommon four-coordinate geometry and fourteenelectron count at each molybdenum atom (Dipp $=2,6-i \mathrm{Pr}_{2} \mathrm{C}_{6} \mathrm{H}_{3}$ ). The coordination polyhedron approaches a square pyramid with one of the molybdenum atoms nearly co-planar with the basal square plane in which the coordination position trans with respect to the Mo-Me bond is empty. The other three sites contain two trans nitrogen atoms of different amidinate ligands and the methyl group. The second Mo atom occupies the apex of the pyramid and forms a Mo-Mo bond of length 2.080 (1) $\AA$, consistent with a quadruple bond. Compound 2 reacts with tetrahydrofuran (THF) and trimethylphosphine to yield the mono-adducts $\left[\mathrm{Mo}_{2} \mathrm{Me}(\mu-\mathrm{Me})\left\{\mu-\mathrm{HC}(\mathrm{NDipp})_{2}\right\}_{2}(\mathrm{~L})\right]$ (3-THF and 3-PMe $\mathbf{P}_{3}$, respectively) with one terminal and one bridging methyl groups. In contrast, 4-dimethylaminopyridine (dmap) forms the bis-adduct $\left[\mathrm{Mo}_{2} \mathrm{Me}_{2}\left\{\mu-\mathrm{HC}(\mathrm{NDipp})_{2}\right\}_{2}(\mathrm{dmap})_{2}\right]$ (4), with terminally coordinated methyl groups. Hydrogenolysis of complex $\mathbf{2}$ leads to the bis(hydride) $\left[\mathrm{Mo}_{2} \mathrm{H}_{2}\left\{\mu-\mathrm{HC}(\mathrm{NDipp})_{2}\right\}_{2}(\text { thf })_{2}\right]$ (5-THF) with elimination of $\mathrm{CH}_{4}$. Computational, kinetic and mechanistic studies, that include the use of $\mathrm{D}_{2}$, and of complex 2 labelled with ${ }^{13} \mathrm{C}(99 \%)$ at the $\mathrm{Mo}-\mathrm{CH}_{3}$ sites, support the intermediacy of a methyl-hydride reactive species. A computational analysis of the terminal and bridging coordination of the methyl group to the Mo $\equiv$ Mo core is also reported.
\end{abstract}

\section{Introduction}

In the course of ongoing studies on binuclear molybdenum compounds with $\mathrm{M}-\mathrm{M}$ quadruple bonds we became interested in preparing alkyl and aryl complexes of the $\left(\mathrm{Mo}_{2}\right)^{4+}$ core that could be used as precursors for low-coordinate second-row diorganometal(II) species and for related hydride complexes. As a result of these efforts, a series of mono- and bis-terphenyl complexes $\left[\mathrm{Mo}_{2}\left(\mathrm{Ar}^{\prime}\right)\left(\mathrm{O}_{2} \mathrm{CR}\right)_{3}\right]$ and $\left[\mathrm{Mo}_{2}\left(\mathrm{Ar}^{\prime}\right)_{2}\left(\mathrm{O}_{2} \mathrm{CR}\right)_{2}\right]$, were obtained for different terphenyl ligands $\left(\mathrm{Ar}^{\prime}\right)$ and carboxylate groups. The new compounds displayed a Mo-Mo bond length close to $c a$. $2.10 \AA$, typical of a quadruple bond, and a coordinative and electronic unsaturation partially compensated by the existence of weak Mo- $C_{\text {arene }}$ secondary interactions involving $\eta^{1}$ binding of a flanking aryl ring. ${ }^{[1,2]}$ Latterly, within the same line of research, uncommon lithium di- and trimethyl dimolybdenum(II) ate

\footnotetext{
a. Instituto de Investigaciones Químicas (IIQ), Departamente de Química Inorgánica and Centro de Innovación en Química Avanzada (ORFEO-CINQA). Consejo Superior de Investigaciones Cientificas (CSIC) and Universidad de Sevilla. Avda. Américo Vespucio, 49, 41092 Sevilla (Spain).

b. Departament de Química Inorgànica and Institut de Química Teòrica I Computacional. Universitat de Barcelona. Martí i Franquès 1-11, 08028 Barcelona (Spain).

Electronic Supplementary Information (ESI) available: NMR and crystallographic table. CCDC 1449191-1449194. See DOI: 10.1039/x0xx00000x
}

complexes in which the unprecedented trimetallic agostic structure $\mathbf{A}\left(\mathrm{S}=\mathrm{Et}_{2} \mathrm{O}, \mathrm{THF}\right)$ is stabilized by metal coordination to auxiliary pyridylamido (also called aminopyridinate) and amidinate ligands were also investigated. ${ }^{[3]}$

\section{A}

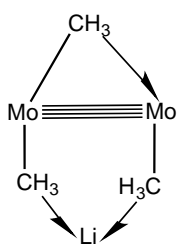

(S)<smiles>C#CN(C=Nc1c(C(C)C)cccc1C(C)C)c1c(C(C)C)cccc1C(C)C</smiles>

2
The methyl group is the simplest alkyl function. Be that as it may, it can adopt a variety of coordination modes in its interaction with transition metal centres. Thus, besides common terminal binding, $\mathrm{M}-\mathrm{Me}$, it can perform a bridging role, $M(\mu-M e) M$, generating a variety of structures ${ }^{[4-7]}$ that encompass the symmetrical pyramidal and the monohapto agostic binding forms depicted in Figure 1. ${ }^{[8,9]}$ Even if a large number of methyl complexes of molybdenum is presently 
known, information on compounds of this sort that contain the $\left(\mathrm{Mo}_{2}\right)^{4+}$ central unit is scarce. ${ }^{[10]}$<smiles>[M]C([M])[CH]</smiles><smiles>[M]CC([M])[M]</smiles>

Fig. 1. Half-arrow representations for non-agostic $\mu^{\mathrm{sp}}{ }^{3} \mathrm{c}-\mathrm{Me}$ (left) and monohapto agostic $\mu^{1 \mathrm{H}}-\mathrm{Me}$ (right) bridging methyl groups (see ref. 8).

In 1974 the pyrophoric salt $[\mathrm{Li}(\mathrm{thf})]_{4}\left[\mathrm{Mo}_{2} \mathrm{Me}_{8}\right]$ was prepared by Cotton, Wilkinson and co-workers and found to exhibit a Mo-Mo bond distance of 2.148(2) $\AA$ and Mo-Me bond lengths in the range ca. 2.27-2.31 $\AA^{.}{ }^{[11]}$ The structures of neutral complexes of composition $\left[\mathrm{Mo}_{2} \mathrm{Me}_{4}\left(\mathrm{PR}_{3}\right)_{4}\right]\left(\mathrm{PR}_{3}=\mathrm{PMe}_{3}\right.$, $\mathrm{PMe}_{2} \mathrm{Ph}$ ) were later ascertained with similar Mo-Mo (ca. 2.15 $\AA \AA$ ) and Mo-Me $\left(2.25 \AA\right.$ ) bond distances. ${ }^{[12]}$ No other methyl $\left(\mathrm{Mo}_{2}\right)^{4+}$ complexes seem to have been described with the exception of the mentioned ate complexes recently reported by our group, that were isolated as lithium derivatives with either contact ion pair or solvent-separated ion pair formulations. Some methyl derivatives with Mo-Mo bonds of order lower than four have also been described. [13-16]

Transition metal organometallics that possess structures of low coordination number and low electron count are reactive species in a number of catalytic reactions. ${ }^{[17]}$ Furthermore, their unsaturated metal centres can provide active frames for the activation of small molecules such as $\mathrm{H}_{2}{ }^{[18]}$ or $\mathrm{N}_{2}{ }^{[19]}$. In the field of molecular metal-metal multiple bonds, unusual physical properties and reactivity patterns have been disclosed in unsaturated complexes of chromium, molybdenum and other metals. ${ }^{[20-25]}$ In this article we report the synthesis and structural characterization by NMR, X-ray and computational methods of the four coordinate, fourteen-electron dimethyl complex $\left[\mathrm{Mo}_{2} \mathrm{Me}_{2}\left\{\mu-\mathrm{HC}(\mathrm{NDipp})_{2}\right\}_{2}\right]$ (2) (Dipp = 2,6-i $\mathrm{Pr}_{2} \mathrm{C}_{6} \mathrm{H}_{3}$ ). This compound has a salient solid-state structure (B) with terminal methyl groups and coordinatively and electronically unsaturated metal atoms. In accordance with these features, it reacts readily with tetrahydrofuran and $\mathrm{PMe}_{3}$ to yield the monoadducts $\left[\mathrm{Mo}_{2} \mathrm{Me}(\mu-\mathrm{Me})\left\{\mu-\mathrm{HC}(\mathrm{NDipp})_{2}\right\}_{2}(\mathrm{~L})\right]$ (3-THF and 3.PMe $\mathbf{P}_{3}$, and with 4-dimethylaminopyridine (dmap) to afford the bis-adduct $\left[\mathrm{Mo}_{2} \mathrm{Me}_{2}\left\{\mu-\mathrm{HC}(\mathrm{NDipp})_{2}\right\}_{2}(\mathrm{dmap})_{2}\right]$ (4). As discussed in detail below, while in complex $\mathbf{2}$ and in the latter complex 4 the two methyl groups form normal 2c-2e Mo- $\mathrm{CH}_{3}$ bonds, in the two complexes $\mathbf{3}$ one of the methyl groups bridges the two molybdenum atoms and participates in a monohapto agostic interaction. ${ }^{[8-9]}$ Complex 2 reacts with $\mathrm{H}_{2}$ to generate the bis(hydride) derivative $\left[\mathrm{Mo}_{2} \mathrm{H}_{2}\{\mu-\right.$ $\left.\mathrm{HC}(\mathrm{NDipp})_{2}\right\}_{2}(\text { thf })_{2}$ ] (5), previously characterized by our group. ${ }^{[26]}$ Kinetic, mechanistic and computational studies on this reaction, that include the use of samples of $\mathbf{2}$ and 3.THF labelled with ${ }^{13} \mathrm{C}$ at the $\mathrm{Mo}-\mathrm{CH}_{3}$ sites, support the intermediacy of the methyl-hydride species $\left[\mathrm{Mo}_{2}\left(\mathrm{CH}_{3}\right)(\mathrm{H})\{\mu\right.$ $\left.\left.\mathrm{HC}(\text { NDipp })_{2}\right\}_{2}(\text { thf })_{2}\right](6 \cdot T H F)$.

\section{Results and Discussion}

As cited in the introductory comments, we have recently characterized some lithium trimethyl dimolybdenum(II) ate complexes that exhibit an unprecedented $\mathrm{Li}(\mu-\mathrm{Me}) \mathrm{Mo}(\mu-\mathrm{Me}) \mathrm{Mo}(\mu-\mathrm{Me})$ trimetallic core (structure A), supported by coordination to two bridging aminopyridinate or amidinate ligands. Even if the amidinate derivative, which has composition $\left[\mathrm{Mo}_{2}(\mu-\mathrm{Me})\left\{(\mu-\mathrm{Me})_{2} \mathrm{Li}(\mathrm{THF})\right\}\left\{\mu-\mathrm{HC}(\mathrm{NDipp})_{2}\right\}_{2}\right]$ (1), was obtained by the reaction of the bis(acetate)bis(amidinate) precursor $\left[\mathrm{Mo}_{2}\left(\mu-\mathrm{O}_{2} \mathrm{CMe}\right)_{2}\left\{\mu-\mathrm{HC}(\mathrm{NDipp})_{2}\right\}_{2}\right] \quad$ (Dipp $=2,6-$ $\left.i \mathrm{Pr}_{2} \mathrm{C}_{6} \mathrm{H}_{3}\right)$ with an excess of LiMe, in some instances, NMR analysis of the reaction mixtures suggested the formation of small quantities of a lithium-devoid neutral methyl derivative, of the $\left(\mathrm{Mo}_{2}\right)^{4+}$ central unit. It was assumed that the new species contained a $\left[\mathrm{Mo}_{2} \mathrm{Me}_{2}\right]$ core, and accordingly, we set out to isolate this compound. We found that heating at $100^{\circ} \mathrm{C}$ for 3-5 hours toluene or toluene-hexane solutions of 1 resulted in the elimination of LiMe and formation of the dimethyl complex 2 (Scheme 1). To avoid contamination by tetrahydrofuran (THF), that reacts instantly with $\mathbf{2}$ to yield the corresponding adduct 3.THF (vide infra), solid 2 was treated twice with $5 \mathrm{~mL}$ of pentane, stirred for $15 \mathrm{~min}$ and thoroughly dried in vacuo (see Experimental Section). Crystallization from toluene at $-23^{\circ} \mathrm{C}$ afforded very air sensitive red crystals of the desired product.
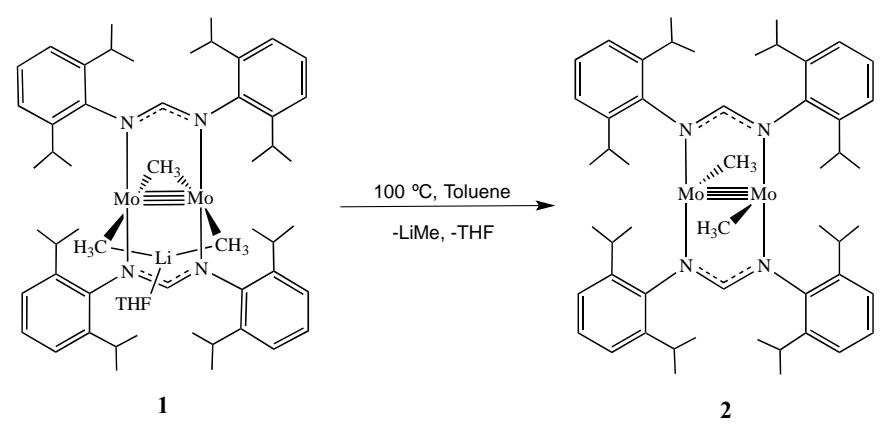

Scheme 1 Synthesis of unsaturated complex 2.

Complex 2 did not react with either $\mathrm{CO}_{2}\left(2 \mathrm{bar}, 12 \mathrm{~h}, 25^{\circ} \mathrm{C}\right)$ or $\mathrm{C}_{2} \mathrm{H}_{4}\left(0.5\right.$ bar, $\left.12 \mathrm{~h}, 60^{\circ} \mathrm{C}\right)$. In contrast, its treatment with LiMe at room temperature in a 1:1 molar ratio (Scheme 2) gave cleanly compound $\mathbf{1}$, that was characterized by comparison of its NMR data with those of an authentic sample. ${ }^{[3]}$ New complexes formed when $\mathbf{2}$ was reacted with an excess of $\mathrm{THF}, \mathrm{PMe}_{3}$ and 4-dimethylaminopyridine (dmap). While THF and $\mathrm{PMe}_{3}$ yielded mono-adducts, 3.THF and 3. $\mathrm{PMe}_{3}$, 
respectively, the pyridinic ligand with smaller cone angle $\left(101.1^{\circ} \text { for pyridine, vs } 118^{\circ} \text { for } \mathrm{PMe}_{3}\right)^{[27]}$ afforded the bis(adduct) 4. Under similar conditions, no observable reaction took place between complex $\mathbf{2}$ and the bulkier phosphine $\mathrm{PMe}_{2} \mathrm{Ph}$ (cone angle $122^{\circ}$ ), ${ }^{[27 \mathrm{~b}]}$ probably as a consequence of steric hindrance.

Complex 3.THF was isolated as an oxygen- and moisturesensitive red crystalline solid, following crystallization from a toluene:THF solvent mixture. As represented in Scheme 2, it converted back to the solvent free complex $\mathbf{2}$ by action of vacuum, at room temperature or slightly above $\left(c a .40^{\circ} \mathrm{C}\right)$. The solvated complex has, however, enhanced thermal stability in comparison with the base-free complex $\mathbf{2}$ and slightly reduced reactivity towards oxygen and water. Since, in addition, the coordinated THF is highly labile (see below), 3.THF was commonly used in place of $\mathbf{2}$ for many of the reactivity studies that will be discussed in the following paragraphs (see Scheme 2). The new complexes represented in Scheme 2 were characterized by microanalysis, NMR spectroscopy and X-ray crystallography. For the study of the reaction of $\mathbf{2}$ with $\mathrm{H}_{2}$, to be analysed in a forthcoming section, samples of this complex and of the adducts 3.THF and 3.PMe $\mathbf{P M}_{3}$ enriched in ${ }^{13} \mathrm{C}(99 \%)$ at the $\mathrm{Mo}-\mathrm{CH}_{3}$ sites were prepared. Their examination by variable temperature NMR spectroscopy proved valuable for structural assignment. The ${ }^{1} \mathrm{H}$ NMR spectrum of complex 2 $\left(\mathrm{C}_{7} \mathrm{D}_{8}, 25^{\circ} \mathrm{C}\right)$ contains two septets ( 3.54 and $4.25 \mathrm{ppm}$ ) and four doublets (in the interval 1.0-1.4 ppm) for the eight iso-propyl substituents of the two amidinate ligands, coherent with the molecular symmetry proposed for this complex. In addition, a singlet at $\delta 1.89$ can be attributed to the two equivalent $\mathrm{Mo}-\mathrm{CH}_{3}$ units. The corresponding ${ }^{13} \mathrm{C}$ resonance appears at $14.7 \mathrm{ppm}$ and is characterized by a ${ }^{1} \mathrm{~J}_{\mathrm{CH}}$ coupling constant of $120 \mathrm{~Hz}$. These data are consistent with terminal coordination of the methyl groups. ${ }^{[3]}$ Low temperature ${ }^{13} \mathrm{C}\left\{{ }^{1} \mathrm{H}\right\}$ studies of complex 2 enriched in ${ }^{13} \mathrm{C}$ were undertaken (Figure S1). Upon cooling at $-20^{\circ} \mathrm{C}$ the $14.7 \mathrm{ppm}$ resonance broadens, and it fades into the base line when the temperature drops to $-40^{\circ} \mathrm{C}$. Then it merges at $-60^{\circ} \mathrm{C}$ with $\delta 15.5 \mathrm{ppm}$, to become broader at $-70^{\circ} \mathrm{C}$, and then disappear again into the base line when the temperature decreases to $-85^{\circ} \mathrm{C}$. By comparison with the dynamic behaviour of 3.THF (vide infra) the higher energy dynamic process (coalescence temperature $-40^{\circ} \mathrm{C}$ ) can be attributed to equilibration of complex $\mathbf{2}$ with small, undetected amounts of its THF adduct (originated by minor amounts of THF). In turn, the lower energy process (coalescence at $-85^{\circ} \mathrm{C}$ ) could tentatively be viewed as involving an isomeric $\mathrm{Mo}_{2}(\mu-$ $\mathrm{Me})_{2}$ bridging structure, although the lack of computational support in favour of this formulation (see below) casts doubts on the participation of such an species. An alternative possibility could be the attainment at very low temperatures of a weak $\varepsilon$-agostic interaction of the kind hinted by the X-ray data to be discussed in an upcoming section.

The ${ }^{1} \mathrm{H}$ NMR spectrum of 3.THF $\left(\mathrm{C}_{6} \mathrm{D}_{6}, 25^{\circ} \mathrm{C}\right)$ shows only one resonance at $1.89 \mathrm{ppm}$ attributable to the metal-bonded methyl protons, which is clearly in disagreement with the formulation presented in Scheme 2 that contains one terminal and one bridging methyl ligands. The corresponding ${ }^{13} \mathrm{C} N \mathrm{NMR}$ resonance appears with $\delta 15.9$ and has a ${ }^{1} J_{\mathrm{CH}}$ coupling constant of $118 \mathrm{~Hz}$. Similarly, the iso-propyl substituents of the amidinate ligands of 3.THF give rise to a pattern of signals that resembles that discussed above for the parent complex 2 (i.e. two septets at 3.81 and $4.04 \mathrm{ppm}$ and four doublets in the range $1.0-1.4 \mathrm{ppm}$ ). All these data are in agreement with fast dissociation of the coordinated molecule of THF, a process that slows down considerably upon cooling at lower temperatures. Thus, only a broad hump centred at $16.1 \mathrm{ppm}$ is observed at $-20^{\circ} \mathrm{C}$ in the ${ }^{13} \mathrm{C}\left\{{ }^{1} \mathrm{H}\right\}$ NMR of a sample of 3.THF enriched in ${ }^{13} \mathrm{C}$ (Figure S2) that becomes broader with further cooling, such that cannot be distinguished from the base line between -30 and $-40^{\circ} \mathrm{C}$. Extra cooling to $-60^{\circ} \mathrm{C}$ causes, however, the appearance of three signals with chemical shifts 13.5, 15.5 and $21.2 \mathrm{ppm}$. The central one corresponds to complex 2, whereas the other two can be respectively ascribed to the terminal and bridging methyl groups of complex 3.THF by comparison with compound 3. $\mathrm{PMe}_{3}$ (see below) and with other $\mathrm{Mo} \equiv \mathrm{\equiv o}$ complexes that contain terminal and bridging methyl groups. ${ }^{[3]}$ 


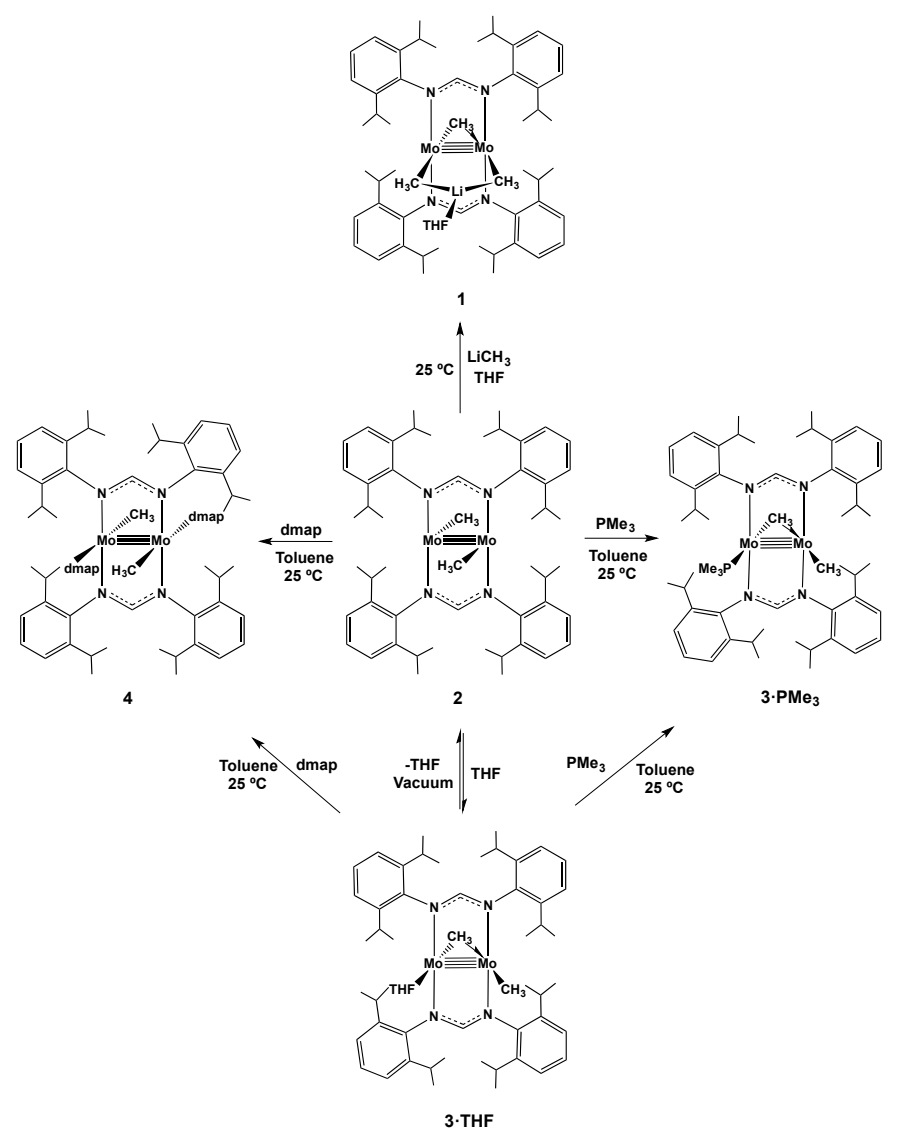

Scheme 2 Reactivity of complex 2 toward different Lewis bases and generation of complexes 3.PMe 3 and 4 from 3.THF.

As depicted in Scheme 2 , the reaction of $\mathbf{2}$ or 3.THF with $\mathrm{PMe}_{3}$ (ca. 1.5 equiv) generated cleanly the analogous adduct 3. $\mathrm{PMe}_{3}$ for which a similar structure containing terminal and bridging methyl groups can also be proposed. Notwithstanding, the room temperature ${ }^{1} \mathrm{H},{ }^{13} \mathrm{C}\left\{{ }^{1} \mathrm{H}\right\}$ and ${ }^{31} \mathrm{P}\left\{{ }^{1} \mathrm{H}\right\}$ NMR spectra feature broad resonances indicating that phosphine dissociation is fast under these conditions. Upon cooling at $-45^{\circ} \mathrm{C}\left(\mathrm{C}_{7} \mathrm{D}_{8}\right)$ the broad room temperature ${ }^{31} \mathrm{P}\left\{{ }^{1} \mathrm{H}\right\}$ NMR signal of 3.PMe $\mathbf{P M}_{3}$ centred at -27 ppm converts into a sharp singlet with $\delta-23.4$. Similarly, two broad ${ }^{1} \mathrm{H}$ NMR resonances are recorded at $-45^{\circ} \mathrm{C}$ with $\delta 0.25$ and 1.37 , due respectively to the terminal and bridging Mo-bonded methyl protons. The corresponding ${ }^{13} \mathrm{C}$ NMR signals appear at $17.5\left({ }^{1} J_{\mathrm{CH}}=115 \mathrm{~Hz}\right)$ and $2.5 \mathrm{ppm}\left({ }^{1} \mathrm{~J}_{\mathrm{CH}}=115 \mathrm{~Hz} ;{ }^{2} J_{\mathrm{CP}}=40 \mathrm{~Hz}\right)$. In the ${ }^{13} \mathrm{C}\left\{{ }^{1} \mathrm{H}\right\} \mathrm{NMR}$ spectrum of ${ }^{13} \mathrm{C}$-labelled $\mathbf{3} \cdot \mathrm{PMe}_{3}$ the $\mathrm{Mo}\left(\mu-{ }^{13} \mathrm{CH}_{3}\right) \mathrm{Mo}$ resonance appears as a doublet of doublets due to an additional ${ }^{2} J_{\mathrm{CC}}$ coupling of $5 \mathrm{~Hz}$, whereas that due to the terminal $\mathrm{Mo}-{ }^{13} \mathrm{CH}_{3}$ group (17.5 ppm) becomes somewhat broad, presumably, due to unresolved two-bond ${ }^{13} \mathrm{C}-{ }^{13} \mathrm{C}$, and three-bond ${ }^{13} \mathrm{C}-31 \mathrm{P}$ couplings. These signals coalesce at $25^{\circ} \mathrm{C}$ (Figure S3; see the Supporting Information) and at $66^{\circ} \mathrm{C}$ give rise to a broad singlet centred in the proximity of $10.3 \mathrm{ppm}$. Using the slow-exchange approximation ${ }^{[28]}$ the rate constant at the coalescence temperature $\left(c a .25^{\circ} \mathrm{C}\right)$ was calculated to be $k$ $=13060 \mathrm{~s}^{-1}$, with a corresponding $\Delta G^{\neq}$value of $11.8 \mathrm{kcal} \cdot \mathrm{mol}^{-1}$. By contrast, the pyridinic adduct 4 contains two coordinated molecules of 4-dimethylaminopyridine and therefore two terminal Mo-Me bonds. This complex was obtained employing either $\mathbf{2}$ or 3.THF as precursors (Scheme 2). In contrast with the monoadducts 3.THF and 3.PMe $\mathbf{P M}_{3}$, complex $\mathbf{4}$ has a rigid structure in solution under ambient conditions, the most distinctive NMR signals being the ${ }^{1} \mathrm{H}$ and ${ }^{13} \mathrm{C}$ resonances due to the equivalent $\mathrm{Mo}-\mathrm{CH}_{3}$ functions that appear respectively at 1.84 and $14.7 \mathrm{ppm}$. The latter exhibits a one-bond ${ }^{13} \mathrm{C}-{ }^{1} \mathrm{H}$ coupling constant of $120 \mathrm{~Hz}$.

As already indicated, the neutral dimethyl complexes 2, 3.THF, 3.PMe $\mathbf{P M}_{3}$ and $\mathbf{4}$ were characterized by single-crystal X-ray studies and their molecular structures are represented in Figures 2, 3, 4 and 5, respectively. Figure 2 contains two ORTEP perspective views of the molecules of $\mathbf{2}$ that emphasize their coordinative unsaturation. For each Mo atom the coordination polyhedron approaches closely a square pyramid in which one of the basal coordination sites (namely that trans relative to the $\mathrm{Mo}-\mathrm{CH}_{3}$ bond) is empty. The other three are occupied by two trans nitrogen atoms of different amidinate ligands and by the methyl group. Each Mo centre is nearly coplanar with its bonded donor atoms, although it is slightly displaced from this plane (by ca. $0.08 \AA$ ) toward the other molybdenum atom that occupies the apex of the pyramid. The Mo-Mo bond distance of 2.080 (1) $\AA$ is consistent with a metal-metal quadruple bond. The Me-Mo-Mo bond angles (ca. 93 $3^{\circ}$ and the Mo-Me bond lengths (ca. $2.19 \AA$ A) are in accord with terminal coordination of the methyl groups.

As can also be seen in Figure 2 (bottom view) in the solid state two $\mathrm{H}$ atoms that belong to methyl groups of iso-propyl substituents of each amidinate ligand hover over the vacant 
coordination site of the molybdenum centres. The MowH distance is however long ( $2.7 \AA$ ) and the $\mathrm{C}-\mathrm{H} \cdots \mathrm{Mo}$ angle large $\left(149.5^{\circ}\right)$. The two parameters are well above the range expected for agostic interactions $\left(\sim 1.8-2.3 \AA\right.$ and $\left.90-140^{\circ}\right) . .^{[9]}$ It therefore seems that complex $\mathbf{2}$ is a genuinely unsaturated, four-coordinate dimolybdenum complex and the marked unsaturation of its metal atoms is only compensated by feeble $\varepsilon$-agostic interactions. This conclusion is in accordance with the solution NMR data already discussed. A three-coordinate quadruply bonded complex $\left[\mathrm{Mo}_{2}\left(\mu-\eta^{2}-\mathrm{Me}_{2} \mathrm{Si}(\mathrm{NDipp})_{2}\right\}_{2}\right]$ has been reported. However, this compound exhibits a long Mo-Mo quadruple bond (2.1784(12) $\AA$ ) and fairly short Mo-N bonds $(1.958(4) \AA)$ that are indicative of $\sigma$ - and $\pi$-donor coordination behaviour of the amido nitrogen atoms. [29]

The $\left(\mathrm{MO}_{2}\right)^{4+}$ core of adducts 3.THF, 3. $\mathbf{P M e}_{3}$ and 4 is characterized by a slightly longer Mo-Mo bond of length in the range 2.086-2.110 $\AA$, the longest distance $(2.110(1) \AA)$ corresponding to complex 4. The $\mathrm{Mo}_{2}\left(\mu-\mathrm{N}^{\wedge} N\right)_{2}$ framework that supports the coordinated methyl and neutral Lewis base ligands in these complexes $\left(\mathrm{N}^{\wedge} \mathrm{N}\right.$ represents the amidinate ligand) exhibits in all cases similar structural parameters that are also close to the corresponding metrics in 2. Thus, Mo-N distances range between $c a .2 .13$ and $2.22 \AA$, trans $\mathrm{N}-\mathrm{Mo}-\mathrm{N}$ bond angles have values of roughly $170^{\circ}$ and Mo-Mo-N angles are of about $92^{\circ}$ (both kinds of bond angles are close to the ideal 180 and $90^{\circ}$ values).

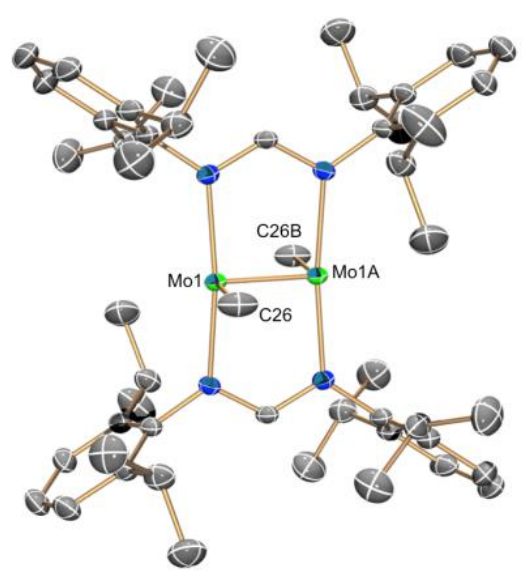

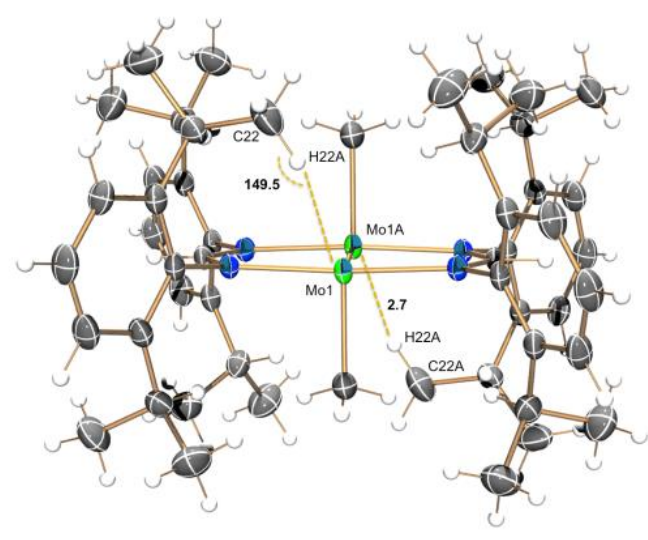

Fig. 2. X-ray molecular structure of $\left[\mathrm{Mo}_{2} \mathrm{Me}_{2}\left\{\mu-\mathrm{HC}(\mathrm{NDipp})_{2}\right\}_{2}\right]$ (2), emphasizing the coordinative unsaturation of the Mo atoms (above) and the possible existence of weak $\varepsilon$-agostic interactions (bottom drawing). Anisotropic displacement parameters drawn at the $50 \%$ level. Selected bond lengths $(\AA \AA)$ and angles $\left({ }^{\circ}\right)$ : $\mathrm{Mo}(1)-\mathrm{Mo}(1 \mathrm{~A})$, 2.080(1); $\mathrm{Mo}(1)-C(26), 2.189(3) ; \mathrm{Mo}(1 \mathrm{~A})-\mathrm{Mo}(1)-C(26), 92.8(1)$.

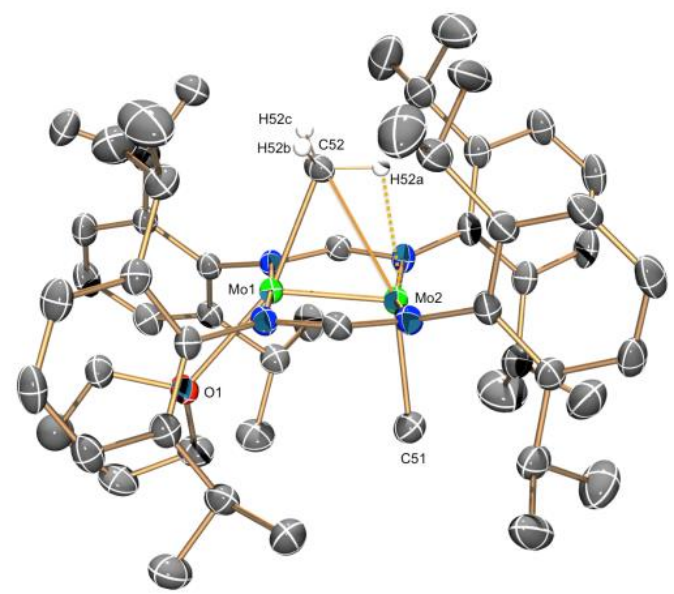

Fig. 3. The solid state molecular structure of the tetrahydrofuran adduct $\left[\mathrm{Mo}_{2} \mathrm{Me}(\mu-\right.$ $\left.\mathrm{Me})\left\{\mu-\mathrm{HC}(\mathrm{NDipp})_{2}\right\}_{2}(\mathrm{THF})\right]$. Solid-state molecular structure of complex 3.THF with thermal ellipsoids set at $50 \%$ probability. Hydrogen atoms have been omitted for clarity. Selected bond lengths ( $\AA$ ) and angles ( $\left.{ }^{\circ}\right)$ : $\mathrm{Mo}(1)-\mathrm{Mo}(2), 2.086(1)$; $\mathrm{Mo}(1)-\mathrm{O}(1), \quad 2.258(2) ; \quad \mathrm{Mo}(1)-\mathrm{C}(52), \quad 2.220(3) ; \mathrm{Mo}(2)-\mathrm{C}(52), \quad 2.573(3)$; $\mathrm{Mo}(2)-\mathrm{C}(51), \quad 2.214(3) ; \quad \mathrm{C}(52)-\mathrm{Mo}(1)-\mathrm{O}(1), \quad 160.4(1) ; \quad \mathrm{C}(52)-\mathrm{Mo}(2)-\mathrm{C}(51)$, 156.7(1); $\quad \mathrm{Mo}(1)-\mathrm{C}(52)-\mathrm{Mo}(2), \quad 51.0(1) ; \quad \mathrm{O}(1)-\mathrm{Mo}(1)-\mathrm{Mo}(2), \quad$ 126.3(1); $\mathrm{Mo}(1)-\mathrm{Mo}(2)-\mathrm{C}(51), 101.0(1)$.

The two terminal $\mathrm{Mo}-\mathrm{CH}_{3}$ bonds of $\mathbf{4}$ have normal[12-16] lengths (ca. $2.24 \AA$ ) although they are somewhat longer than the terminal Mo- $\mathrm{CH}_{3}$ unit of 3.THF (2.21 $\AA$ ) and 3. $\mathrm{PMe}_{3}(2.19$ $\AA$ )), perhaps as a consequence of the superior coordination number of the molybdenum atoms. However, in the latter two complexes there is a bridging methyl group that originates an acute Mo-C-Mo angle (approximately $51^{\circ}$ ) and Mo-C bonds 
that differ appreciably in length. These Mo-C distances have values of 2.220(3) and 2.573(3) $\AA$ in 3.THF and of 2.292(2) and 2.492(2) $\AA$ in the $\mathrm{PMe}_{3}$ complex analogue. In each case the shorter Mo-C bond is approximately trans with respect to the neutral Lewis base (C-Mo-O and C-Mo-P angles of 160.4(1) and $166.1(1)^{\circ}$, respectively), and the difference between the shorter Mo-C bonds in the two complexes is doubtless due to the diverse trans influence exerted by the THF and $\mathrm{PMe}_{3}$ ligands. ${ }^{[30]}$ The bond angle that at the pertinent Mo atom encompasses the terminal and bridging methyl groups in these complexes amounts $156.7(1)$ and $175.5(1)^{\circ}$ in 3.THF and 3. $\mathrm{PMe}_{3}$, respectively.

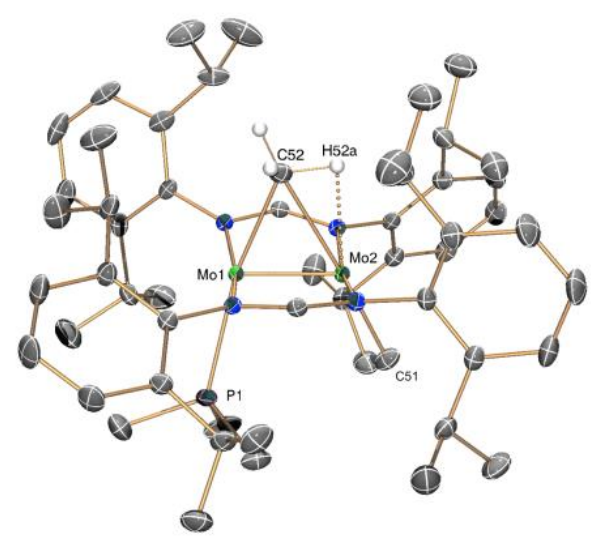

Fig. 4. Solid-state molecular structures of complexes $\mathbf{3} \cdot \mathrm{PMe}_{3}$ with thermal ellipsoids set at $50 \%$ probability. Selected bond lengths $(\AA)$ and angles ( $\left.{ }^{\circ}\right)$ : $\mathrm{Mo}(1)-\mathrm{Mo}(2), 2.088(1)$; $\mathrm{Mo}(1)-\mathrm{P}(1), \quad 2.591(1) ; \quad \mathrm{Mo}(1)-\mathrm{C}(52), \quad 2.292(2) ; \quad \mathrm{Mo}(2)-\mathrm{C}(52), \quad 2.492(2) ;$ $\mathrm{Mo}(2)-\mathrm{C}(51), \quad 2.192(2) ; \quad \mathrm{C}(52)-\mathrm{Mo}(1)-\mathrm{P}(1), \quad 166.1(1) ; \quad \mathrm{C}(52)-\mathrm{Mo}(2)-\mathrm{C}(51)$, 175.5(1); $\quad \mathrm{Mo}(1)-\mathrm{C}(52)-\mathrm{Mo}(2), \quad 51.5(1) ; \quad \mathrm{P}(1)-\mathrm{Mo}(1)-\mathrm{Mo}(2), \quad$ 102.3(1); $\mathrm{Mo}(1)-\mathrm{Mo}(2)-\mathrm{C}(51), 117.2(1)$.

Notwithstanding the uncertainties in defining the positions of hydrogen atoms by X-ray diffraction, the crystallographic data obtained for complexes $\mathbf{3}$ denote the existence in the solid state of a weak monohapto agostic interaction between the $\mathrm{C} 52-\mathrm{H} 52 \mathrm{~A}$ bond an the Mo2 atom (Figures 3 and 4). In addition to the already provided $\mathrm{Mo2}-\mathrm{C} 52$ bond distances $(2.573(3)$ and $2.492(2) \AA)$, this three-centre two-electron interaction (3c-2e) is defined by a Mo2-H52A contact of about $2.28 \AA$ and by a $\mathrm{C}-\mathrm{H}-\mathrm{Mo}$ angle of between ca. 96 and $87^{\circ}$, in the expected ranges for these parameters. ${ }^{[9]}$ Notice, however, that the Mo2-H52A separations are in the upper part of the 1.80-2.30 $\AA$ range considered for agostic interactions and furthermore that they are much longer than the $\mathrm{Mo}-\mathrm{H}$ bonds in the bis(hydride) complex $\left[\mathrm{Mo}_{2} \mathrm{H}_{2}\left\{\mu-\mathrm{HC}(\mathrm{NDipp})_{2}\right\}_{2}(\mathrm{THF})_{2}\right]$ (5.THF) that have lengths of $1.71 \AA{ }^{[26]}$ If one also takes into account that these bridging methyl groups present ${ }^{1} J_{\mathrm{CH}}$ couplings around $118 \mathrm{~Hz}$, it can only be concluded that these agostic interactions must be weak. ${ }^{[9,31]}$

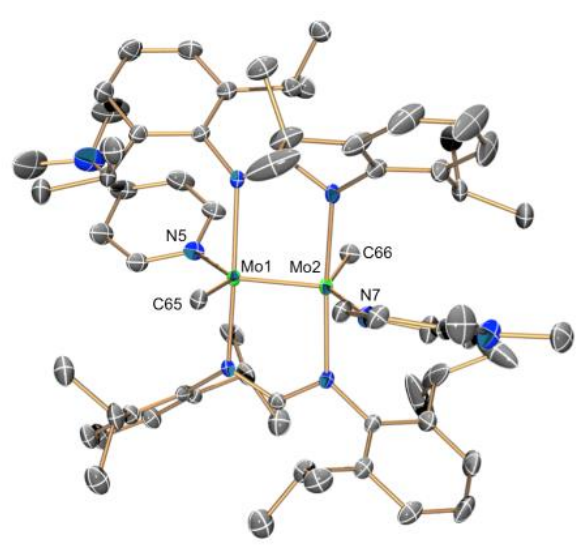

Fig. 5. Solid-state molecular structure of compound $\mathbf{4}$ with thermal ellipsoids set at $50 \%$ probability. All hydrogen atoms have been omitted for clarity. Selected bond lengths (Å) and angles $\left({ }^{\circ}\right)$ : $\mathrm{Mo}(1)-\mathrm{Mo}(2), \quad 2.110(1) ; \mathrm{Mo}(1)-C(65), 2.236(2)$; $\mathrm{Mo}(2)-\mathrm{C}(66), \quad 2.247(2) ; \quad \mathrm{Mo}(1)-\mathrm{N}(5), \quad 2.321(2) ; \quad \mathrm{Mo}(2)-\mathrm{N}(7), \quad 2.302(2)$; $\mathrm{C}(65)-\mathrm{Mo}(1)-\mathrm{Mo}(2), \quad 95.3(1) ; \mathrm{Mo}(1)-\mathrm{Mo}(2)-\mathrm{C}(66), \quad 91.9(1) ; \quad \mathrm{N}(5)-\mathrm{Mo}(1)-\mathrm{Mo}(2)$, 128.0(1); $\quad \mathrm{Mo}(1)-\mathrm{Mo}(2)-\mathrm{N}(7), \quad 124.3(1) ; \quad \mathrm{N}(5)-\mathrm{Mo}(1)-\mathrm{C}(65), \quad$ 136.6(1); $\mathrm{N}(7)-\mathrm{Mo}(2)-\mathrm{C}(66), 143.6(1)$.

Geometry optimization of the base-free, trans complex 2 gave a structure in good agreement with the experimental one, with a terminal Me group bonded to each Mo atom. The cis isomer was found to correspond also to an energy minimum $5.8 \mathrm{kcal} / \mathrm{mol}$ higher in energy than the trans one. The lower stability of the cis isomer is most likely associated to steric repulsion between the two methyl groups, as suggested by Mo-Mo-Me bond angles of $104^{\circ}$, to be compared with $94^{\circ}$ in the trans isomer. No energy minimum could be found for an alternative geometry with two bridging Me groups.

The special bonding topology of the quadruply bonded $\mathrm{Mo}_{2}$ $\mathrm{Me}_{2}\left(\mathrm{~N}^{\wedge} \mathrm{N}\right)_{2}$ preserves the $\mathrm{Mo}_{2}\left(\mathrm{~N}^{\wedge} \mathrm{N}\right)_{2}$ skeleton of the quintuply bonded precursor while the Mo atoms present an unusual square pyramidal coordination geometry with a vacant basal position. In the $\mathrm{Mo}_{2}\left(\mathrm{~N}^{\wedge} \mathrm{N}\right)_{2}$ fragment the $\delta$-type orbital that points in the direction of the $\mathrm{N}$-donor ligands becomes the LUMO, which is allowed by symmetry to mix in some metal $\mathrm{s}$ orbital contribution (Scheme 3, $D_{2 h}\left(A_{g}\right)$ ), thus hybridizing the $d$ orbitals in the direction perpendicular to the $\mathrm{Mo}_{2}\left(\mathrm{~N}^{\wedge} \mathrm{N}\right)_{2}$ plane. Upon symmetry descent to that of the $\mathrm{Mo}_{2} \mathrm{Me}_{2}\left(\mathrm{~N}^{\wedge} \mathrm{N}\right)_{2}$ complex (from $D_{2 \mathrm{~h}}$ to $C_{2 \mathrm{~h}}$ ), further hybridization with metal $\mathrm{p}$ orbitals is possible, resulting in a fragment orbital with two lobes in the right directions to act as acceptors toward donor fragments. A similar hybridization scheme applies to the corresponding $\delta^{*}$ orbital that yields an out-of-phase version of the acceptor orbital shown in Scheme 3, thus accounting for two possible donor-acceptor interactions with incoming ligands. 


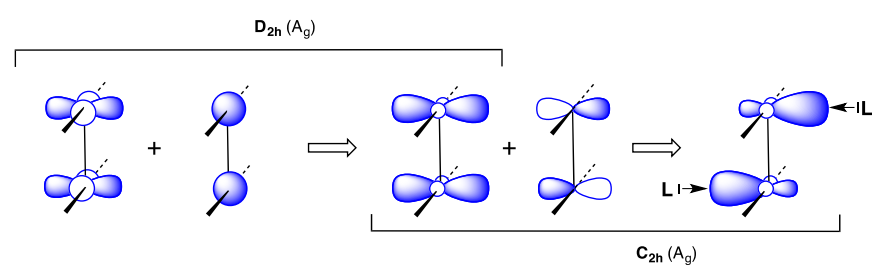

Scheme 3 Hybridization of d orbitals.

The calculated in-phase Mo-Me $\sigma$-bonding orbital, shown in Figure 6 clearly shows the hybridization expected from Scheme 3. Moreover, one can also observe some mixing-in of the $\sigma$ bonding combination of the $\mathrm{z}^{2}$ orbitals that belongs to the same symmetry representation. A similar mixing of $\delta$ and $\sigma$ metal-metal bonding components has already been detected in $\mathrm{Cr}-\mathrm{Cr}$ quintuply bonded systems. ${ }^{[32]}$

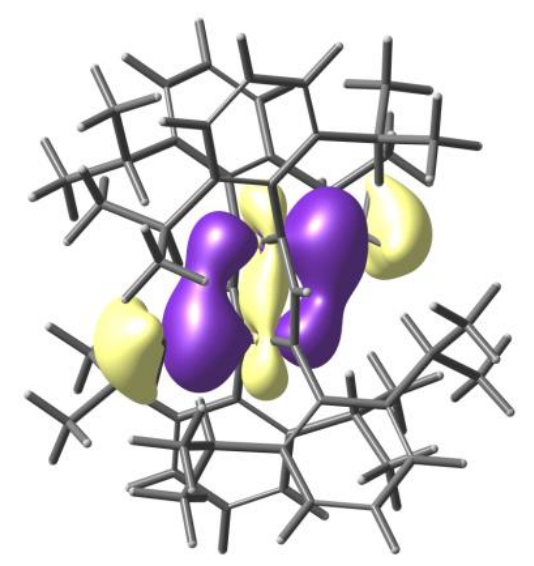
Fig. 6. $\mathrm{A}_{\mathrm{g}}$ molecular orbital incorporating Mo-Mo $\delta+\sigma$ and Mo-Me $\sigma$ bonding
character.

\section{Reactivity of Complexes $\mathbf{2}$ and 3.THF toward dihydrogen}

Complexes 2 (plus added THF) and 3.THF reacted cleanly at room temperature with $\mathrm{H}_{2}$ (1.5 bar) in toluene, with elimination of $\mathrm{CH}_{4}$, to afford the known bis(hydride) $\left[\mathrm{Mo}_{2} \mathrm{H}_{2}\{\mu\right.$ $\left.\left.\mathrm{HC}(\mathrm{NDipp})_{2}\right\}_{2}(\text { thf })_{2}\right](\mathbf{5} \cdot \mathrm{THF})$, in essentially quantitative yield (by ${ }^{1} \mathrm{H}$ NMR spectroscopy). In contrast, no reaction was observed between $\mathrm{CH}_{4}$ and complex 2 enriched in ${ }^{13} \mathrm{C}$ (99\%) at the $\mathrm{Mo}-\mathrm{CH}_{3}$ sites, at temperatures of $60-80^{\circ} \mathrm{C}$, and a pressure of 40 bar of methane.

To investigate the mechanism of the hydrogenolysis reaction, a kinetic study was carried out. Initially, adduct 3-THF containing small amounts of tetrahydrofuran was utilized as a surrogate for 2. Using ${ }^{1} \mathrm{H}$ NMR spectroscopy, the reaction rate was determined in $\mathrm{C}_{7} \mathrm{D}_{8}$ at $0^{\circ} \mathrm{C}$ under the pseudo-first-order conditions created by a dihydrogen pressure of 5 bar. A graphical concentration vs. time representation (Figure S4; see the Supporting Information) indicated not only first-order dependence on the concentration of 3.THF, further confirmed by the straight line plot of the logarithmic function $\operatorname{In}$ [3-THF] vs. time (Figure S5), but also the appearance of an intermediate, 6.THF, that reached maximum concentration approximately upon completion of the first half-life (ca. 40 min) and subsequently decayed into product 5.THF. It was therefore clear that the overall transformation consisted of two consecutive irreversible pseudo-first-order reactions, of which the first was somewhat slower than the second. ${ }^{[32]} A$ computer fit of experimental data to theoretically predicted consecutive rate constants led to approximate $k_{\text {obs } 1}$ and $k_{\text {obs2 }}$ values of $3 \times 10^{-4}$ and $8 \times 10^{-4} \mathrm{~s}^{-1}$, respectively. It seems reasonable to propose that the reactive intermediate $\mathbf{6} \cdot \mathbf{T H F}$ has a methyl-hydride formulation, $\left[\mathrm{Mo}_{2}(\mathrm{Me})(\mathrm{H})\right]$, and this hypothesis was confirmed by mechanistic studies to be described below (Scheme 4).

To avoid the unnecessary kinetic complications due to coordinated THF in the above study of dihydrogen activation, a kinetic analysis of the analogous transformation of the Lewis base-free complex $\mathbf{2}$ was undertaken. Once more, reaction rates were measured in $\mathrm{C}_{7} \mathrm{D}_{8}$ under pseudo-first-order conditions over a $\mathrm{H}_{2}$ pressure in the interval from 5 to 9 bar. Graphical representations of $\ln$ [2] vs. time (Figures S6) yielded straight lines in accordance with first-order dependence on the concentration of $\mathbf{2}$. Furthermore, a plot of the observed rate constants against the concentration of $\mathrm{H}_{2}$ was also linear (Figure 7A), indicating that the reaction was also first-order in dihydrogen. The concentration of dihydrogen in the samples was determined using ferrocene as an internal reference. The variation of $k$ as a function of the reaction temperature was ascertained over the temperature range 288 to $318 \mathrm{~K}$. An Eyring representation (Figure 7B) provided values of the activation parameters $\Delta H^{\neq}=12.5(1.7) \mathrm{kcal} \cdot \mathrm{mol}^{-1}, \Delta S^{\neq}=-28.0$

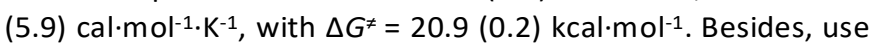
of $\mathrm{D}_{2}$ (Figure S7) provided a kinetic isotope effect $k_{\mathrm{H}} / k_{\mathrm{D}}$ of 2.9 , indicating that cleavage of the $\mathrm{H}-\mathrm{H}$ bond was rate determining. 

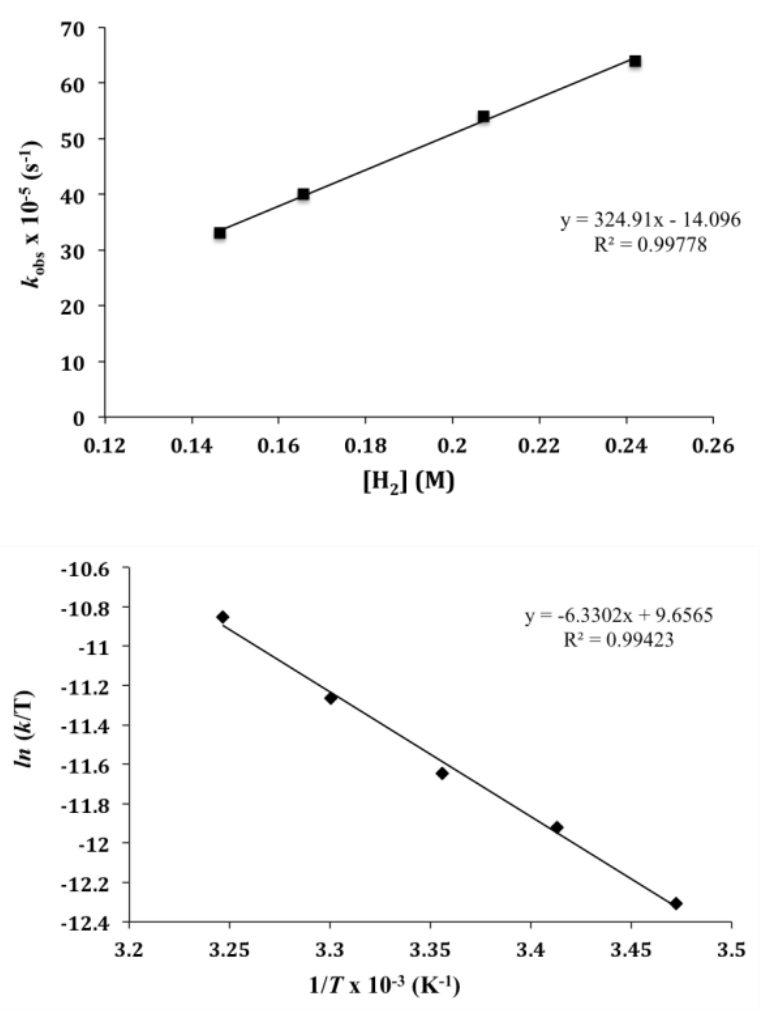

A intermediate, further experimental work was accomplished. The purported hydride-methyl species was also detected in the reaction of $\mathbf{2}$ with $\mathrm{H}_{2}$ although it was more difficult to observe due to faster reaction rates in comparison with 3.THF. Accordingly, the latter complex was utilized for these studies that were performed in an NMR tube with $C_{7} D_{8}$ as the solvent.

Treatment of a $\mathrm{C}_{7} \mathrm{D}_{8}$ solution of 3.THF with 1.5 bar of $\mathrm{H}_{2}$ produced after $\mathrm{ca} .30 \mathrm{~min}$ at $25^{\circ} \mathrm{C}$ a mixture of unreacted 3.THF, the bis(hydride) product 5.THF and the hydride-methyl complex 6.THF (Scheme 4) in an approximate 2:1:1 ratio. The reaction was quenched by removal of $\mathrm{H}_{2}$, and a slight excess of $\mathrm{PMe}_{3}$ (ca. 1.5 equiv. relative to 3.THF) was added at $25^{\circ} \mathrm{C}$, to convert the above mixture of products into the corresponding $\mathrm{PMe}_{3}$ adducts, 3.PMe, $\mathbf{3} \cdot \mathbf{P M e}_{3}$ and 6.PMe $\mathbf{P}_{3}$. The complete experiment was repeated utilizing $D_{2}$ instead of $H_{2}$, and furthermore the 3.PMe $\mathbf{P M}_{3} \mathbf{5} \cdot \mathbf{P M e}_{3}: \mathbf{6} \cdot \mathbf{P M e}_{3}$ mixture was also engendered starting from 3.THF enriched in ${ }^{13} \mathrm{C}(99 \%)$ at the $\mathrm{Mo}-\mathrm{CH}_{3}$ sites. For experimental convenience, to avoid overlap of signature resonances, ${ }^{1} \mathrm{H}$ and ${ }^{31} \mathrm{P} N M \mathrm{~N}$ identification of the aforementioned mixtures was effected at $-10^{\circ} \mathrm{C}$, whereas ${ }^{13} \mathrm{C}$ NMR spectra were measured at $0^{\circ} \mathrm{C}$. Fig. 7. Plot of pseudo-first-order rate constant $\left(k_{\text {obs }}\right) v s$. $\mathrm{H}_{2}$ concentration $(\mathbf{A})$ and
Eyring representation $(\mathbf{B})$ for the hydrogenolysis of complex 2 .

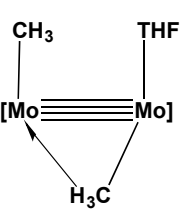

3.THF

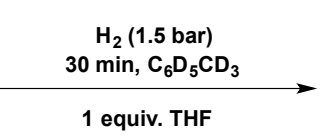

1 equiv. THF

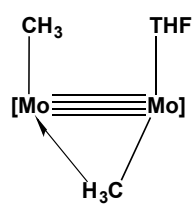

3.THF (unreacted)

\section{)}

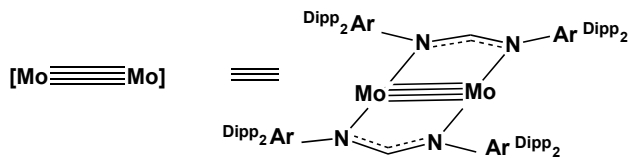

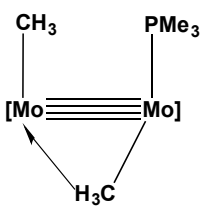

3. $\mathrm{PMe}_{3}$
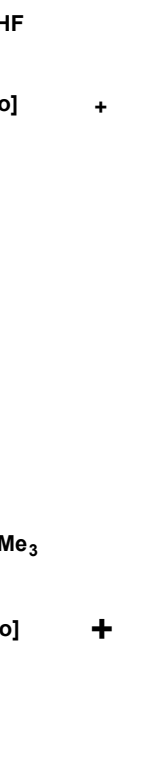

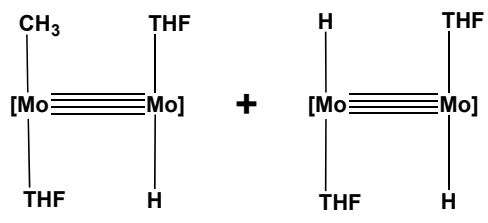

6.THF

5.THF

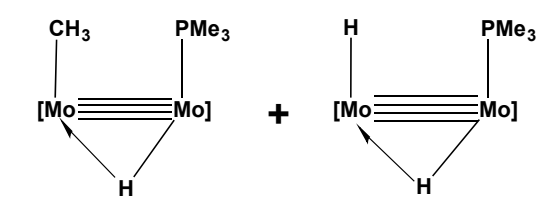

6. $\mathrm{PMe}_{3}$

$\mathrm{PMe}_{3}, 25^{\circ} \mathrm{C}$

$\downarrow$

5. $\mathrm{PMe}_{3}$

Scheme 4 Products of the NMR-tube reaction of 3.THF and $\mathrm{H}_{2}$ quenched after $c a .50 \%$ conversion and generation of the corresponding PMe 3 adducts. The $3 \mathrm{c}-2 \mathrm{e}$ interactions are depicted using the half-arrow notation proposed by Green, Green and Parking. ${ }^{[8]}$ The bridging amidinate ligands have been omitted for the sake of clarity. 
Identification of the individual components of the foregoing miscellanies of products by multinuclear NMR spectroscopy was straightforward. Thus complexes 3.THF 3. $\mathrm{PMe}_{3}, \mathbf{5} \cdot \mathrm{THF}$ and $\mathbf{5} \cdot \mathrm{PMe}_{3}$ (in the pertinent isotopologue forms) were authenticated by comparison of their NMR parameters with those of authentic samples.[26a,33] Signature NMR data for the pursued intermediates 6.THF and 6. $\mathbf{P M e}_{3}$ provided strong support for the hydride-methyl formulation proposed in Scheme 4. Particularly noteworthy are the following: (i) A ${ }^{31} \mathrm{P} \mathrm{NMR}$ resonance at $-10^{\circ} \mathrm{C}$ for $6 \cdot \mathrm{PMe}_{3}$ characterized by $\delta-12.7,2 J_{\mathrm{PH}}=60$ and $2 J_{\mathrm{PD}}=9 \mathrm{~Hz}$. (ii) The Mo- $\mathrm{CH}_{3}$ group of 6. $\mathrm{PMe}_{3}$ is responsible for a ${ }^{13} \mathrm{C}$ resonance at ca. $17 \mathrm{ppm}$ that exhibits ${ }^{1} \mathrm{~J}_{\mathrm{CH}},{ }^{3} \mathrm{CH}_{\mathrm{CH}}$ and ${ }^{3} \mathrm{~J}_{\mathrm{CP}}$ coupling constants of 116, 18 and $2 \mathrm{~Hz}$, respectively. In 6.THF enriched in ${ }^{13} \mathrm{C}$ this signal appears at $18.2 \mathrm{ppm}$ although an additional ${ }^{3} \mathrm{~J}_{\mathrm{CH}}$ coupling with the hydride ligand of $17 \mathrm{~Hz}$ becomes discernable $\left({ }^{1} J_{\mathrm{CH}}=\right.$ $115 \mathrm{~Hz}$ ). (iii) The Mo-H resonance of 6.THF appears at 6.23 (ca. $6.1 \mathrm{ppm}$ in the deuterated isotopologue). This chemical shift is very close to that recorded for the bis(hydride) complex 5.THF (5.7 Hz; ca. $5.8 \mathrm{ppm}$ for the bis-deuteride isotopologue).

A detailed mechanism for the hydrogenation reaction of 2 can be obtained from a computational study of stationary points along the potential energy surface along a path that takes from 2 to $\mathbf{6}$. The species that have been found as stationary points along such path, their relative energies and some relevant bond distances and angles are shown in Scheme 5. The approach of $\mathrm{H}_{2}$ to the dimolybdenum species $\mathbf{2}$ yields a transition state (TS1) with a side-on orientation relative to a Mo atom. This transition state corresponds to the point at which $\mathrm{H}_{2}$ passes in between three Me groups, two from the aryl groups of the amidinate ligands coordinated to the Mo atom being approached, and the Me group coordinated to the other Mo atom (seven $\mathrm{H}-\mathrm{H} \cdots \mathrm{H}-\mathrm{C}$ distances between 2.31 and $2.59 \AA$ A). Then it proceeds to an intermediate (Int) with a $\sigma$ bond coordinated $\mathrm{H}_{2}$, with the $\mathrm{H}-\mathrm{H}$ and Mo-Mo bonds perpendicular to each other. Then, rotation of $\mathrm{H}_{2}$ forms an incipient $\mathrm{H}-\mathrm{C}$ bond with a methyl group, while the other $\mathrm{Me}$ adopts a bridging coordination mode in a transition state (TS2). The next step seems to consist in a concerted bond reorganization that results in the liberation of a methane molecule and the transfer of the other methyl group to the non-hydrogenated Mo atom to give the detected intermediate 6. The free energy change for this whole process is -24.1 $\mathrm{kcal} / \mathrm{mol}$. The rate determining step is the formation of the TS2 transition state that involves significant lengthening of the Mo-Me bond to the leaving methyl group, and partial formation of a new $\mathrm{H}-\mathrm{Me}$ bond. This mechanism is consistent with the kinetic studies that show the rate of the reaction to be dependent of the partial pressure of $\mathrm{H}_{2}$.

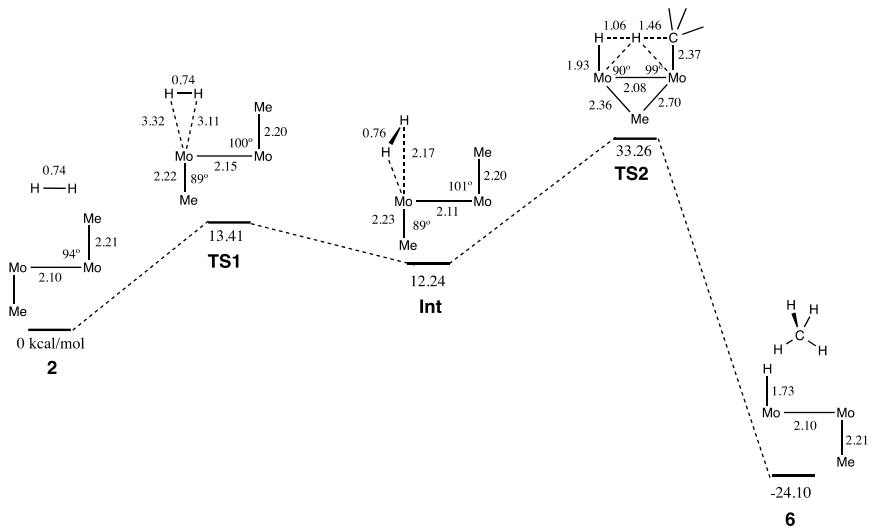

Scheme 5. Stationary points along hydrogenation reaction of $\mathbf{2}$ and their relative energies. Some relevant bond distances and angles are also shown.

Subsequent hydrogenation of 6 follows a similar path (Scheme 6), the main qualitative difference being that in the rate determining transition state (TS4) there is now a bridging hydride instead of the bridging methyl in TS2. The relative energies of the two transition states, the intermediate and the final product are similar to those of the first hydrogenation, if slightly lower. Again in this second reaction, the rate determining step implies the activation of the Mo-Me and $\mathrm{H}-\mathrm{H}$ bonds.

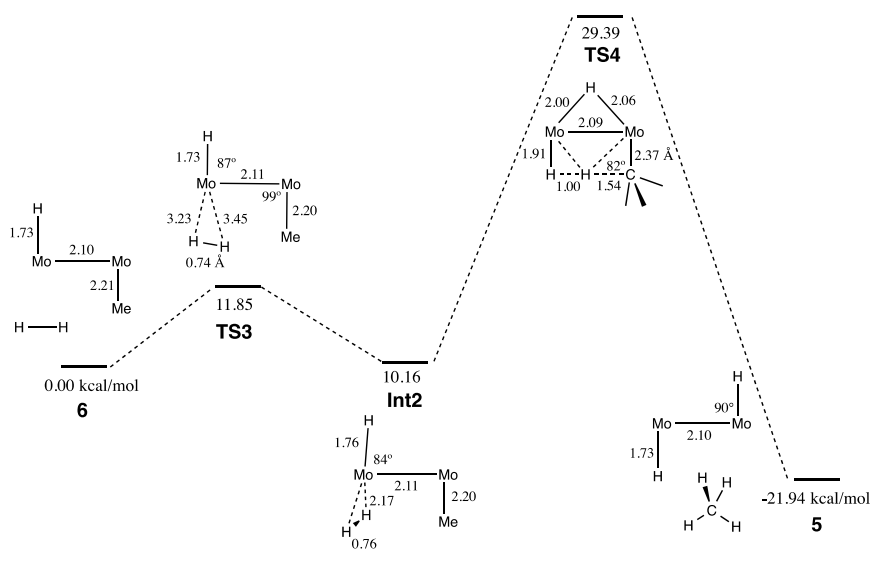

Scheme 6. Stationary points along subsequent hydrogenation reaction of $\mathbf{6}$ and their relative energies. Some relevant bond distances and angles are also shown.

\section{Experimental section}

\section{General considerations}

All manipulations were carried out using standard Schlenk and glove-box techniques, under an atmosphere of argon and of high purity nitrogen, respectively. All solvents were dried, stored over $4 \AA$ molecular sieves, and degassed prior to use. Toluene $\left(\mathrm{C}_{7} \mathrm{H}_{8}\right), n$-pentane $\left(\mathrm{C}_{5} \mathrm{H}_{12}\right)$ and $n$-hexane $\left(\mathrm{C}_{6} \mathrm{H}_{14}\right)$ were distilled under nitrogen over sodium. Tetrahydrofuran (THF) and diethyl ether were distilled under nitrogen over 
sodium/benzophenone. $\left[D_{6}\right]$ Benzene and $\left[D_{8}\right]$ THF were distilled under argon over sodium/benzophenone; $\left[D_{8}\right]$ toluene was distilled under argon over sodium. The quadruply bonded complex $\left[\mathrm{Mo}_{2}(\mu-\mathrm{Me})(\mu-\mathrm{Me})_{2} \mathrm{Li}(\mathrm{thf})\left\{\mu-\mathrm{HC}(\mathrm{NDipp})_{2}\right\}_{2}\right] \quad$ (1) was prepared as described previously. ${ }^{[3]}$ Solution NMR spectra were recorded on Bruker AMX-300, DRX-400 and DRX-500 spectrometers. Spectra were referenced to external $\mathrm{SiMe}_{4}(\delta$ : $0 \mathrm{ppm}$ ) using the residual proton solvent peaks as internal standards $\left({ }^{1} \mathrm{H}\right.$ NMR experiments), or the characteristic resonances of the solvent nuclei ( ${ }^{13} \mathrm{C} N M R$ experiments), while ${ }^{31} \mathrm{P}$ was referenced to $\mathrm{H}_{3} \mathrm{PO}_{4}$. Spectral assignments were made by routine one- and two-dimensional NMR experiments $\left({ }^{1} \mathrm{H}\right.$, ${ }^{13} \mathrm{C},{ }^{13} \mathrm{C}\left\{{ }^{1} \mathrm{H}\right\},{ }^{31} \mathrm{P}\left\{{ }^{1} \mathrm{H}\right\}$, COSY, NOESY, HSQC and $\mathrm{HMBC}$ ) where appropriate. UV-visible spectra were recorded on a Perkin Elmer Lambda 750 spectrometer. For elemental analyses a LECO TruSpec CHN elementary analyzer, was utilized.

\section{Synthesis of $\left[\mathrm{Mo}_{2}(\mathrm{Me})_{2}\left\{\mu-\mathrm{HC}(\mathrm{NDipp})_{2}\right\}_{2}\right]$ (2)}

The complex $\left[\mathrm{Mo}_{2}(\mu-\mathrm{Me})\left\{(\mu-\mathrm{Me})_{2} \mathrm{Li}(\mathrm{THF})\right\}\left\{\mu-\mathrm{HC}(\mathrm{NDipp})_{2}\right\}_{2}\right]$ (1), was generated from $\left[\mathrm{Mo}_{2}\left(\mu-\mathrm{O}_{2} \mathrm{CMe}\right)_{2}\left\{\mu-\mathrm{HC}(\mathrm{NDipp})_{2}\right\}_{2}\right]$ and LiMe as described previously. ${ }^{[3]}$ A solution of $\mathbf{1}$ in toluene $(0.8$ g, ca. $0.6 \mathrm{mmol}, 15 \mathrm{~mL}$ ) was heated at $100{ }^{\circ} \mathrm{C}$ for 3 hours and it was then cooled down to room temperature, filtered and evaporated to dryness. Pentane $(2 \times 5 \mathrm{~mL})$ was added and the resulting suspension was stirred at room temperature for 15 min before removal of the solvent. The red-brown solid that was obtained was further dried under vacuum for $1 \mathrm{~h}$ and redissolved in toluene ( $c a .0 .5 \mathrm{~g}$ of the complex in $10 \mathrm{~mL}$ of the solvent) with warming at around $60^{\circ} \mathrm{C}$. The resulting concentrated solution was kept at $-23^{\circ} \mathrm{C}$ for two days to give red crystals of complex 2 (0.2 g, $42 \%) .{ }^{1} \mathrm{H}$ NMR ( $400 \mathrm{MHz}, \mathrm{C}_{6} \mathrm{D}_{6}$, $\left.25^{\circ} \mathrm{C}\right): \delta=1.01,1.16,1.26,1.37\left(\mathrm{~d}, 12 \mathrm{H}\right.$ each, $3 J_{\mathrm{HH}}=6.7 \mathrm{~Hz}$, $\mathrm{Me}_{\text {Dipp }}$ ), 1.89 (s, $6 \mathrm{H}, \mathrm{Mo}-\mathrm{Me}_{\mathrm{t}}$ ), 3.54, 4.25 (sept, $4 \mathrm{H}$ each, ${ }^{3}{ }_{\mathrm{HH}}=$ $6.7 \mathrm{~Hz}, \mathrm{CHMe}$ ), $6.92\left(\mathrm{dd}, 4 \mathrm{H},{ }^{3} J_{\mathrm{HH}}=7.5 \mathrm{~Hz},{ }^{4} J_{\mathrm{HH}}=1.2 \mathrm{~Hz}, m-\right.$ Dipp), 7.03 (apparent t, $4 \mathrm{H}, 3^{3} \mathrm{HH}_{\mathrm{H}}=7.5 \mathrm{~Hz}, p$-Dipp), 7.09 (dd, 4 $\mathrm{H},{ }^{3} J_{\mathrm{HH}}=7.5 \mathrm{~Hz},{ }^{4} \mathrm{~J}_{\mathrm{HH}}=1.2 \mathrm{~Hz}, m^{\prime}$-Dipp), $8.31(\mathrm{~s}, 2 \mathrm{H}, \mathrm{NC}(H) \mathrm{N})$. The signal ' designs the groups closer to the methyl group (Mo$\left.\mathrm{CH}_{3}\right) .{ }^{13} \mathrm{C}\left\{{ }^{1} \mathrm{H}\right\}$ NMR $\left(100 \mathrm{MHz}, \mathrm{C}_{6} \mathrm{D}_{6}, 25^{\circ} \mathrm{C}\right): \delta=14.7$ (s, Mo-Me $\left.e_{\mathrm{t}}\right)$, 25.0, 25.1, 25.3, 26.0 (Me $\left.\mathrm{Mipp}_{\text {Di }}\right), 28.3,29.7\left(\mathrm{CHMe}_{2}\right), 123.5(\mathrm{~m}-$ Dipp), 124.9 ( $m^{\prime}$-Dipp), 126.3 ( $p$-Dipp), 143.9 (o'-Dipp), 144.9 (o-Dipp), 145.4 (ipso-Dipp), $161.6(\mathrm{NC}(\mathrm{H}) \mathrm{N})$. The signal designs the groups closer to the methyl group $\left(\mathrm{Mo}-\mathrm{CH}_{3}\right) \cdot{ }^{13} \mathrm{C}$, ${ }^{1} \mathrm{H}$ NMR $\left(100 \mathrm{MHz}, \mathrm{C}_{6} \mathrm{D}_{6}, 25^{\circ} \mathrm{C}\right): \delta=14.7\left(\mathrm{q},{ }^{1} \mathrm{~J}_{\mathrm{CH}} \sim 120 \mathrm{~Hz}\right.$, Mo-Met $e_{\mathrm{t}}$. Elemental analysis calcd. (\%) for $\mathrm{C}_{52} \mathrm{H}_{76} \mathrm{Mo}_{2} \mathrm{~N}_{4}$ : C, 65.81; H, 8.07; N, 5.90. Expt.: C, 66.0; H, 8.4; N, 6.1.

\section{Synthesis of $\left[\mathrm{Mo}_{2}(\mu-\mathrm{Me})(\mathrm{Me})\left\{\mu-\mathrm{HC}(\mathrm{NDipp})_{2}\right\}_{2}(\right.$ thf $\left.)\right]$ (3-THF)}

Procedure A. Red crystals of the title complex were obtained from a saturated solution of complex $\mathbf{2}(0.6 \mathrm{~g})$ in a mixture of toluene $(7 \mathrm{~mL})$ and THF $(0.3 \mathrm{~mL})$ at $-23^{\circ} \mathrm{C}$ for 2 days $(310 \mathrm{mg}$, $48 \%)$. Procedure B. A solution of complex $1(2.0 \mathrm{~g}, 1.6 \mathrm{mmol})$ in toluene $(30 \mathrm{~mL})$ was heated at $100^{\circ} \mathrm{C}$ for 3 hours. The reaction mixture was filtered and the red solution was dried under vacuum (340 mg, 67\%). ${ }^{1} \mathrm{H}$ NMR ( $\left.400 \mathrm{MHz}, \mathrm{C}_{6} \mathrm{D}_{6}, 25^{\circ} \mathrm{C}\right): \delta$ $=1.08,1.15\left(\mathrm{~d}, 12 \mathrm{H}\right.$ each, $\left.{ }^{3} J_{\mathrm{HH}}=6.8 \mathrm{~Hz}, \mathrm{Me}_{\text {Dipp }}\right), 1.26(\mathrm{~m}, 4 \mathrm{H}$, $\mathrm{O}-\mathrm{CH}_{2} \mathrm{CH}_{2}$ ), 1.33, $1.36\left(\mathrm{~d}, 12 \mathrm{H}\right.$ each, $\left.3 J_{\mathrm{HH}}=6.8 \mathrm{~Hz}, \mathrm{Me}_{\text {Dipp }}\right), 1.89$ (s, $\left.6 \mathrm{H}, \mathrm{Mo}-\mathrm{Me}_{\mathrm{t}}\right), 3.39\left(\mathrm{~m}, \mathrm{O}-\mathrm{CH}_{2} \mathrm{CH}_{2}\right), 3.81,4.04$ (sept, 4H each, ${ }^{3} J_{\mathrm{HH}}=6.8 \mathrm{~Hz}, \mathrm{CHMe}$ ), 6.98-7.06 (m, $m$-Dipp, $m^{\prime}$-Dipp y $p$-Dipp), $8.28(\mathrm{~s}, 2 \mathrm{H}, \mathrm{NC}(H) \mathrm{N}) .{ }^{13} \mathrm{C}\left\{{ }^{1} \mathrm{H}\right\} \mathrm{NMR}\left(100 \mathrm{MHz}, \mathrm{C}_{6} \mathrm{D}_{6}, 25^{\circ} \mathrm{C}\right): \delta=$ 15.9 (s, Mo-Me $e_{\mathrm{t}}$ ), 24.9, 25.0 (Me Dipp), $25.7\left(\mathrm{O}-\mathrm{CH}_{2} \mathrm{CH}_{2}\right), 26.3$, 26.7 (Me $\mathrm{Mipp}), 28.5,28.7\left(\mathrm{CHMe}_{2}\right), 68.2\left(\mathrm{O}-\mathrm{CH}_{2} \mathrm{CH}_{2}\right), 124.1$, 124.2 (m-Dipp), 126.0 (p-Dipp), 144.5, 145.0 (o-Dipp), 145.9 (ipso-Dipp), $162.0(\mathrm{NC}(\mathrm{H}) \mathrm{N})$. The signal' designs the groups closer to the methyl group $\left(\mathrm{Mo}-\mathrm{CH}_{3}\right) \cdot{ }^{13} \mathrm{C}\left\{{ }^{1} \mathrm{H}\right\} \mathrm{NMR}(100 \mathrm{MHz}$, $\left.\mathrm{C}_{6} \mathrm{D}_{6}, 25^{\circ} \mathrm{C}\right): \delta=15.9\left(\mathrm{q},{ }^{1} \mathrm{~J}_{\mathrm{CH}} \sim 118 \mathrm{~Hz}, \mathrm{Mo}-M e_{\mathrm{t}}\right)$.UV-Visible $\left(\mathrm{C}_{6} \mathrm{D}_{6}\right): \lambda_{\max }(\varepsilon)=480 \mathrm{~nm}\left(2160 \mathrm{~mol}^{-1} \mathrm{~L} \mathrm{~cm}^{-1}\right)$. Elemental analysis calcd. (\%) for $\mathrm{C}_{56} \mathrm{H}_{84} \mathrm{Mo}_{2} \mathrm{~N}_{4} \mathrm{O}: \mathrm{C}, 65.87 ; \mathrm{H}, 8.29 ; \mathrm{N}, 5.49$. Found: C, 66.0; H, 8.4; N, 5.7.

\section{Synthesis of $\left[\mathrm{Mo}_{2}(\mu-\mathrm{Me})(\mathrm{Me})\left\{\mu-\mathrm{HC}(\mathrm{NDipp})_{2}\right\}_{2}\left(\mathrm{PMe}_{3}\right)\right]$ (3-PMe $\mathrm{PM}_{3}$}

About $0.5 \mathrm{mmol}$ of either compound 2 or 3.THF was dissolved in toluene $(10 \mathrm{~mL})$ and $\mathrm{PMe}_{3}$ was added dropwise (1.5 equiv) to the solution mixture. After 2 hours of stirring at room temperature the solvent was evaporated in vacuo, and the resulting solid was washed with pentane $(5 \mathrm{~mL})$ at $0^{\circ} \mathrm{C}$. Crystals were obtained from a saturated solution of the complex in toluene at $-23^{\circ} \mathrm{C}$ for 24 hours (340 mg, 67\%). ${ }^{1} \mathrm{H}$ NMR (500 $\left.\mathrm{MHz}, \mathrm{C}_{7} \mathrm{D}_{8},-45^{\circ} \mathrm{C}\right): \delta=0.25\left(\mathrm{~s}, 3 \mathrm{H}, \mathrm{Mo}-\mathrm{Me}_{\mathrm{t}}\right), 0.45,0.67(\mathrm{~d}, 6 \mathrm{H}$ each, Me $\mathrm{Dipp}_{\text {) }}, 0.95$ (m, $\left.9 \mathrm{H}, \mathrm{PMe}\right), 0.97,1.06,1.17$ (s, 6H each, $\left.\mathrm{Me}_{\text {Dipp }}\right), 1.22\left(\mathrm{~m}, 9 \mathrm{H}, \mathrm{Mo}-\mu-M e\right.$ y $\left.\mathrm{Me}_{\text {Dipp }}\right), 1.32,1.37$ (s, 6H each, Me $\mathrm{Dipp}), 3.40\left(\mathrm{~m}, 4 \mathrm{H}, \mathrm{CHMe}_{2}\right), 3.82,3.93$ (m, 2H each, $\mathrm{CHMe}_{2}$ ), 6.8-7.07 (m, $12 \mathrm{H}, m$-Dipp, m'-Dipp y p-Dipp), 8.67 (s, $2 \mathrm{H}, \mathrm{NC}(H) \mathrm{N})$. The signal' designs the groups closer to the methyl group (Mo- $\left.\mathrm{CH}_{3}\right) \cdot{ }^{13} \mathrm{C}\left\{{ }^{1} \mathrm{H}\right\}$ NMR $\left(125 \mathrm{MHz}, \mathrm{C}_{7} \mathrm{D}_{8},-45^{\circ} \mathrm{C}\right)$ : $\left.\delta=2.5\left(\mathrm{~d},{ }^{2} \mathrm{JPC}_{\mathrm{PC}}=40 \mathrm{~Hz}, \mu-\mathrm{Me}\right), 14.4\left(\mathrm{~d},{ }^{1} \mathrm{JPC}_{\mathrm{PC}}=18 \mathrm{~Hz}, \mathrm{PMe}\right)_{3}\right), 17.5$ (Mo-Met $), 23.3,23.5,24.5,24.6,25.7,26.8,27.2,27.4$ (Me Dipp $), 26.7,28.1,28.2,28.3\left(\mathrm{CHMe}_{2}\right), 123.4-125.6$ (m-Dippa , $m^{\prime}$-Dipp ${ }^{\mathrm{a}}, p$-Dipp ${ }^{\mathrm{a}}, m$-Dipp ${ }^{\mathrm{b}}, m^{\prime}$-Dipp ${ }^{\mathrm{b}}$ у $p$-Dipp $\left.{ }^{\mathrm{b}}\right), 141.2,143.2$, 143.3, 144.0 (o-Dipp), 145.8, 145.9 (ipso-Dipp), 162.5 ( $\mathrm{NC}(\mathrm{H}) \mathrm{N})$. The signal ' designs the groups closer to the methyl group (Mo$\left.\mathrm{CH}_{3}\right) \cdot{ }^{13} \mathrm{C},{ }^{1} \mathrm{H}$ NMR $\left(125 \mathrm{MHz}, \mathrm{C}_{7} \mathrm{D}_{8},-45^{\circ} \mathrm{C}\right): \delta=2.5\left(\mathrm{dq},{ }^{1} J_{\mathrm{CH}} \sim 115\right.$ $\left.\mathrm{Hz},{ }^{2} J_{\mathrm{PC} \text { trans }}=40 \mathrm{~Hz}, \mu-M e\right), 17.5\left(\mathrm{q},{ }^{1} J_{\mathrm{CH}} \sim 115 \mathrm{~Hz}\right.$, Mo-Me $\left.e_{\mathrm{t}}\right) \cdot{ }^{31} \mathrm{P}\left\{{ }^{1} \mathrm{H}\right\} \operatorname{NMR}\left(200 \mathrm{MHz}, \mathrm{C}_{7} \mathrm{D}_{8},-45^{\circ} \mathrm{C}\right): \delta=-23.4$. The signals are broad due to the low temperature and the fluxionality of the complex. UV-Visible $\left(C_{6} D_{6}\right): \lambda_{\max }(\varepsilon)=339$, 390 (shoulders), $540 \mathrm{~nm}\left(1270 \mathrm{~mol}^{-1} \mathrm{~L} \mathrm{~cm}^{-1}\right)$. Elemental analysis calcd. (\%) for $\mathrm{C}_{55} \mathrm{H}_{85} \mathrm{Mo}_{2} \mathrm{~N}_{4} \mathrm{P}: \mathrm{C}, 64.44 ; \mathrm{H}, 8.36 ; \mathrm{N}, 5.47$. Found: C, 64.5; H, 8.8; N, 5.9.

\section{Synthesis of $\left[\mathrm{Mo}_{2}(\mathrm{Me})_{2}\left\{\mu-\mathrm{HC}(\mathrm{NDipp})_{2}\right\}_{2}(\mathrm{dmap})_{2}\right]$ (4)}

Starting from complex 2 or 3.THF (ca. $0.2 \mathrm{mmol}$ ) and 4dimethylaminopyridine $(0.06 \mathrm{~g}, 0.5 \mathrm{mmol})$ a toluene solution was prepared $(10 \mathrm{~mL})$ and stirred at room temperature for 5 hours. Concentration of the solvent gave a bright red solid that 
was crystallized from a saturated toluene solution after cooling at $-23^{\circ} \mathrm{C}$ for 3 days $(160 \mathrm{mg}, 65 \%) .{ }^{1} \mathrm{H}$ NMR $\left(500 \mathrm{MHz}, \mathrm{C}_{6} \mathrm{D}_{6}\right.$, $\left.25^{\circ} \mathrm{C}\right): \delta(\mathrm{ppm}): 1.03,1.18,1.30,1.46\left(\mathrm{~d}, 12 \mathrm{H}\right.$ each, $3 J_{\mathrm{HH}}=7.1$ $\mathrm{Hz}, \mathrm{Me}_{\text {Dipp }}$ ), 1.84 (s, 6H, Mo-Me $\left.\mathrm{M}_{2}\right), 2.1\left(\mathrm{~s}, 12 \mathrm{H}, \mathrm{pyr}-\mathrm{NMe}_{2}\right), 3.91$, 4.04 (sept, $4 \mathrm{H}$ each, ${ }^{3} \mathrm{~J}_{\mathrm{HH}}=6.2 \mathrm{~Hz}, \mathrm{CHMe}$ ), 5.89 (broad $\mathrm{s}, 4 \mathrm{H}$, 3,5-pyr), 6.99-6.93 (m, 8H, m'-Dipp, p'-Dipp, $p$-Dipp), 7.01 (dd, $4 \mathrm{H},{ }^{3} J_{\mathrm{HH}}=7.4 \mathrm{~Hz},{ }^{4} J_{\mathrm{HH}}=2.6 \mathrm{~Hz}, m$-Dipp), 8.01 (broad s, $4 \mathrm{H}, 2,6-$ pyr), $8.37(\mathrm{~s}, 2 \mathrm{H}, \mathrm{NC}(H) \mathrm{N})$. The signal' designs the groups closer to the methyl group (Mo- $\left.\mathrm{CH}_{3}\right) \cdot{ }^{13} \mathrm{C}\left\{{ }^{1} \mathrm{H}\right\} \mathrm{NMR}(125 \mathrm{MHz}$, $\left.\mathrm{C}_{6} \mathrm{D}_{6}, 25^{\circ} \mathrm{C}\right): \delta$ (ppm): 14.7 (Mo-Me), 24.3, 24.4, 26.3, 27.5 $\left(\mathrm{CHMe}_{2}\right), 27.8,28.0\left(\mathrm{CHMe}_{2}\right), 37.9$ (pyr-NMe $), 106.4$ (3,5-pyr), 123.0 (m-Dipp), 123.7 (p-Dipp, $p^{\prime}$-Dipp), 124.9 ( $m^{\prime}$ - Dipp), 144.5, 144.7 (o-Dipp, o'-Dipp), 146.5 (ipso-Dipp), 149.2 (2,4pyr), 153.7 (ipso-pyr-NMe2), $161.4(\mathrm{NC}(\mathrm{H}) \mathrm{N})$. The signal ' designs the groups closer to the methyl group $\left(\mathrm{Mo}-\mathrm{CH}_{3}\right) \cdot{ }^{13} \mathrm{C}$, ${ }^{1} \mathrm{H}$ NMR $\left(125 \mathrm{MHz}, \mathrm{C}_{6} \mathrm{D}_{6}, 25^{\circ} \mathrm{C}\right): \delta(\mathrm{ppm}): 14.7\left(\mathrm{q},{ }^{1} \mathrm{~J}_{\mathrm{CH}} \sim 120 \mathrm{~Hz}\right.$, Mo-Me $)_{t}$. UV-Visible $\left(C_{6} D_{6}\right): \lambda_{\max }(\varepsilon)=360,440$ (shoulders), 512 $\mathrm{nm}$ (3150 mol-1 $\left.\mathrm{L} \mathrm{cm}^{-1}\right)$. Elemental analysis calcd (\%) for $\mathrm{C}_{64} \mathrm{H}_{82} \mathrm{Mo}_{2} \mathrm{~N}_{8}$ : C, 66.42; $\mathrm{H}, 8.11 ; \mathrm{N}, 9.39$. Found: $\mathrm{C}, 66.0 ; \mathrm{H}, 8.6$; N, 9.6.

\section{Reactions of complexes 2 and 3.THF with $\mathrm{H}_{2}$}

Complex 2. Complex $2\left(2 \mathrm{mg}, 2 \times 10^{-3} \mathrm{mmol}\right)$ was dissolved in $0.45 \mathrm{~mL}$ of $C_{7} D_{8}$. To this solution, $0.1 \mathrm{~mL}$ of the standard solution of ferrocene in $C_{7} D_{8}(0.0215 \mathrm{M})$ was added. Three vacuum/argon cycles were performed at $203 \mathrm{~K}$ to remove the argon atmosphere in the Young NMR tube. For the different experiments performed, the tube was then charged with 5, 7, 8 or 9 bar of dihydrogen at $203 \mathrm{~K}$ and shaken (Figure S6). The reaction progress was checked by ${ }^{1} \mathrm{H}$ NMR spectroscopy at 298 K. Analogous experiments were carried out with a fixed pressure of 8 bar of dihydrogen at 288, 293, 298, 303 and 308 $K$. To measure the kinetic isotope effect, two identical solutions of complex 2 in $C_{7} D_{8}$ were prepared $\left(2 \mathrm{mg}, 2 \times 10^{-3}\right.$ $\mathrm{mmol})$. After cooling at $203 \mathrm{~K}$, the argon atmosphere was pumped out and the corresponding NMR tubes were charged with a pressure of 5 bar of $\mathrm{H}_{2}$ and $\mathrm{D}_{2}$, respectively (see Figure S7).

Complex 3.THF. Complex 3.THF $\left(2.5 \mathrm{mg}, 2.5 \times 10^{-3} \mathrm{mmol}\right)$ in $0.55 \mathrm{~mL}$ of $\mathrm{C}_{7} \mathrm{D}_{8}$ was cooled to $-70^{\circ} \mathrm{C}$. The argon atmosphere was pumped out and replaced by 4,5 or 6 bars of $\mathrm{H}_{2}$. The reaction progress was checked by ${ }^{1} \mathrm{H}$ NMR spectroscopy at 273 $\mathrm{K}$.

\section{Computational Details}

The calculations were performed with the Gaussian09 computer code. ${ }^{[38]}$ The hybrid B3LYP functional[39] was employed together with the all-electron triple- $\zeta$ basis set proposed by Schäefer et al. ${ }^{[40]}$ for the light atoms while for the molybdenum atoms an all-electron basis set with a contraction
$\{84211111 / 641111 / 51111\}$ was used.[41] This all-electron basis set was used to avoid problems found with common pseudopotentials that provide artifact charge and bond order values for the studied complexes. Transition states and energy minima were corroborated by the calculation of the corresponding frequencies.

\section{Conclusions}

The computational, crystallographic and NMR studies described in this paper underscore that although terminal and bridging coordination of methyl groups to a quadruply bonded $\mathrm{Mo}_{2}$ core have comparable energetics, the former is preferred to the latter. This appears to be a common situation that applies widely to other metal-metal bonded transition metal complexes. ${ }^{[14 a, 34-37]}$ In the context of the work reported herein, it explains the observation in the solid state of the fourcoordinate, fourteen-electron structure of complex 2, in spite of its marked unsaturation, clearly manifested in its reactivity toward conventional Lewis bases and against dihydrogen.

\section{Acknowledgements}

Financial support (FEDER contribution) from the Spanish Ministry of Science and Innovation (Projects CTQ2010-15833, CTQ2013-42501-P, CTQ2014-52769-C3-3-R and ConsoliderIngenio 2010 CSD2007-00006) and the Junta de Andalucía (Grant FQM-119 and Project P09-FQM-5117) is gratefully acknowledged. M.C. and N.C. thank the Spanish Ministry of Education (AP-4193) and the Spanish Ministry of Science and Innovation (BES-2011-047643) for research grants. J.C. thanks the EU 7th Framework Program, Marie Skłodowska-Curie actions (COFUND, Grant Agreement no. 267226) and Junta de Andalucía for a Talentia Postdoc Fellowship. C.M. thanks the Ministry of Economy and Competitiveness for the project CTQ2014-52769-C3-3-R. The group of Homegeneous Catalysis at CIQSO-University of Huelva (Spain) is gratefully acknowledged, in particular Professors P. J. Pérez and T. R. Belderrain, for facilities and assistance in high-pressure reactions.

\section{References}

1 (a) M. Carrasco, M. Faust, R. Peloso, A. Rodríguez, J. LópezSerrano, E. Álvarez, C. Maya, P. P. Power, E. Carmona, Chem. Commun., 2012, 48, 3954-3956; (b) M. Carrasco, I. Mendoza, M. Faust, J. López-Serrano, R. Peloso, A. Rodríguez, E. Álvarez, C. Maya, P. P. Power, E. Carmona, J. Am. Chem. Soc., 2014, 136, 9173-9180.

2 M. Carrasco, I. Mendoza, E. Álvarez, A. Grirrane, C. Maya, R. Peloso, A. Rodríguez, A. Falceto, S. Álvarez, E. Carmona, Chem. - A Eur. J., 2015, 21, 410-421. 
3 N. Curado, M. Carrasco, E. Álvarez, C. Maya, R. Peloso, A Rodríguez, J. López-Serrano, and E. Carmona, J. Am. Chem. Soc., 2015, 137, 12378-12387.

4 For some review articles: (a) J. Holton, M. F. Lappert, R. Pearce, P. I. W. Yarrow, Chem. Rev., 1983, 83, 135-201; (b) P. Braunstein, N. M. Boag, Angew. Chem., Int. Ed., 2001, 40, 2427-2433; (c) J. Campos, J. López-Serrano, R. Peloso, E. Carmona, Chem. Eur. J, 2016, just accepted.

5 (a) J. W. Park, P. B. Mackenzie, W. P. Schaefer, R. H. Grubbs, J. Am. Chem. Soc., 1986, 108, 6402-6404; (b) F. Ozawa, J. W. Park, P. B. Mackenzie, W. P. Schaefer, L. M. Henling, R. H. Grubbs, J. Am. Chem. Soc., 1989, 111, 1319-1327; (c) P. B. Mackenzie, R. J. Coots, R. H. Grubbs, Organometallics, 1989, 8, 8-14; (d) C. P. Casey, P. J. Fagan, W. H. Miles, J. Am. Chem. Soc. 1982, 104, 1134-1136; (e) B. E. Bursten, R. H. Cayton, Organometallics, 1986, 5, 1051-1053.

6 (a) S. D. Stults, R. A. Andersen, A. Zalkin, J. Am. Chem. Soc., 1989, 111, 4507-4508; (b) D. J. Schwartz, G. E. Ball, R. A. Andersen, J. Am. Chem. Soc., 1995, 117, 6027-6040; (c) H. M. Dietrich, H. Grove, K. W. Tömroos, R. Anwander, J. Am. Chem. Soc., 2006, 128, 1458-1459.

7 (a) M. Niemeyer, P. P. Power, Chem. Commun., 1996, 15731574; (b) M. C. W. Chan, J. M. Cole, V. C. Gibson, J. A. K. Howard, Chem. Commun., 1997, 24, 2345-2346; (c) J. R. Wigginton, S. J. Trepanier, R. McDonald, M. J. Ferguson, M. Cowie, Organometallics, 2005, 24, 6194-6211; (d) M.-E. Moret, D. Serra, A. Bach, P. Chen, Angew. Chem., Int. Ed., 2010, 49, 2873-2877.

8 J. C. Green, M. L. H. Green, G. Parkin, Chem. Commun., 2012, 48, 11481-11503.

9 (a) M. Brookhart, M. L. H. Green, J. Organomet. Chem., 1983, 250, 395-408; 408; (b) M. Brookhart, M. L. H. Malcolm, L. L. Wong, Progr. Inorg. Chem., 1988, 36, 1-124; (c) W. Scherer, G. S. McGrady, Angew. Chem. Int. Ed., 2004, 43, 1782-1806; (d) M. Brookhart, M. L. H. Green, G. Parkin, Proc. Natl. Acad. Sci. USA, 2007, 104, 6908-6914; (e) W. Scherer, V. Herz, A Brück, C. Hauf, F. Reiner, S. Altmannshofer, D. Leusser, D. Stalke, Angew. Chem. Int. Ed., 2011, 50, 2845-2849; (f) J.Sabmannshausen, Dalton Trans., 2012, 41, 1919-1923; (g) M. Etienne. A. S. Weller, Chem. Soc. Rev., 2014, 43, 242-259.

10 (a) F. A. Cotton, C. A. Murillo, R. A. Walton, in Multiple Bonds between Metal Atoms, $3^{\text {rd }}$. Ed, Springer Science And Business Media, Inc., New York, 2005; (b) M. H. Chisholm, N. J. Patmore in Molecular Metal-Metal Bonds, Chapter 6 (Ed.: S. T. Liddle), Wiley-VCH Verlag GmbH \& Co. KGaA, Weinheim, 2015.

11 D. H. Williamson, G. Wilkinson, J. Am. Chem. Soc., 1974, 1079, 3824-3828.

12 (a) R. A. Andersen, R. A. Jones, G. Wilkinson, J. Chem. Soc. Dalt. Trans., 1978, 446-453; (b) G. S. Girolami, V. V. Mainz, R. A. Andersen, J. Am. Chem. Soc., 1981, 103, 3953-3955; (c) F. A. Cotton, K. J. Wiesinger, G. S. Girolami, V. V. Mainz, R. A Andersen, Inorg. Chem., 1990, 29, 2594-2599.

13 J. H. Shin, G. Parkin, Chem. Commun., 1998, 1273-1274.

14 (a) M. E. García, A. Ramos, M. A. Ruiz, M. Lanfranchi, L. Marchio, Organometallics, 2007, 26, 6197-6212; (b) M. A. Alvarez, D. García-Vivó, M. E. García, M. E. Martínez, A. Ramos, M. A. Ruiz, Organometallics, 2008, 27, 1973-1975; (c) M. A. Alvarez, M. E. García, M. E. Martínez, A. Ramos, M. A. Ruiz, Organometallics, 2009, 28, 6293-6307; (d) M. A. Alvarez, M. E. García, M. E. Martínez, M. A. Ruiz, Organometallics, 2010, 29, 904-916.

15 J.-G. Ma, Y. Aksu, L. J. Gregoriades, J. Sauer, M. Driess, Dalt Trans., 2010, 39, 103-106.
16 (a) M. H. Chisholm, F. A. Cotton, M. W. Extine, C. A. Murillo, Inorg. Chem., 1978, 17, 2338-2340; (b) M. H. Chisholm, J. C. Huffman, R. J. Tatz, J. Am. Chem. Soc., 1983, 105, 2075-2077.

17 (a) M. Bochmann, in Organometallics and Catalysis. An Introduction, Oxford University Press, Oxford, UK, 2015; (b) J. F. Hartwig, in Organotransition Metal Chemistry, University Science Books, Casebound, 2010; (c) R. H. Crabtree, in The Organometallic Chemistry of the Transition Metals, $6^{\text {th }}$ ed., John Wiley \& Sons, Inc., Hoboken, 2014; (d) C. Elschenbroich, in Organometallics, 3rd ed., Wiley-VCH, Weinheim, 2006.

18 (a) G. J. Kubas, J. Organomet. Chem., 2014, 751, 33-49; (b) S. Ogo, K. Ichikawa, T. Kishima, T. Matsumoto, H. Nakai, K. Kusaka, T. Ohhara, Science, 2013, 339, 682-684; (c) T. Liu, L. DuBois, R. M. Bullock, Nat. Chem., 2013, 5, 228-233; (d) J. M. Camara, T. B. Rauchfuss, Nat. Chem., 2011, 4, 26-30; (e) C. Tsay, J. C. Peters, Chem. Sci., 2012, 3, 1313-1318.

19 (a) D. V. Yandulov, Science, 2003, 301, 76-78; (b) K. Arashiba, Y. Miyake, Y. Nishibayashi, Nat. Chem., 2011, 3, 120-125; (c) J. A. Anderson, J. Rittle, J. C. Peters, Nature, 2013, 501, 8487.

20 (a) T. Nguyen, A. D. Sutton, M. Brynda, J. C. Fettinger, G. J. Long, P. P. Power, Science, 2005, 310, 844-847; (b) R. Wolf, C. Ni, T. Nguyen, M. Brynda, G. J. Long, A. D. Sutton, R. C. Fischer, J. C. Fettinger, M. Hellman, L. Pu, P. P. Power, Inorg. Chem., 2007, 46, 11277-11290; (c) C. Ni, B. D. Ellis, G. J. Long, P. P. Power, Chem. Commun., 2009, 17, 2332-2334.

21 (a) N. V. S. Harisomayajula, A. K. Nair, Y.-C. Tsai, Chem. Commun., 2014, 50, 3391-3412; (b) A. K. Nair, N. V. S. Harisomayajula, Y.-C. Tsai, Inorg. Chim. Acta, 2015, 424, 5162.

22 (a) A. Noor, R. Kempe, Inorganica Chim. Acta, 2015, 424, 7582; (b) C. Schwarzmaier, A. Noor, G. Glatz, M. Zabel, A. Y. Timoshkin, B. M. Cossairt, C. C. Cummins, R. Kempe, M. Scheer, Angew. Chem. Int. Ed., 2011, 50, 7283-7286; (c) A. Noor, G. Glatz, R. Müller, M. Kaupp, S. Demeshko, R. Kempe, Nat. Chem., 2009, 1, 322-325.

23 (a) J. Shen, G. P. A. Yap, J.-P. Werner, K. H. Theopold, Chem. Commun., 2011, 47, 12191-12193; (b) J. Shen, G. Yap, K. Theopold, Chem. Commun., 2014, 50, 2579-2581.

24 (a) J. P. Krogman, C. M. Thomas, Chem. Commun., 2014, 50, 5115-5127; (b) B. G. Cooper, J. W. Napoline, C. M. Thomas, Cat. Rev. Sci. Eng., 2012, 54, 1-40.

25 (a) S. J. Tereniak, R. K. Carlson, L. J. Clouston, V. G. Young, E. Bill, R. Maurice, Y.-S. Chen, H. J. Kim, L. Gagliardi, C. C. Lu, J. Am. Chem. Soc., 2014, 136, 1842-1855; (b) L. J. Clouston, R. B. Siedschlag, P. A. Rudd, N. Planas, S. Hu, A. D. Miller, L. Gagliardi, C. C. Lu, J. Am. Chem. Soc., 2013, 135, 1314213148; (c) R. J. Eisenhart, P. A. Rudd, N. Planas, D. W. Boyce, R. K. Carlson, W. B. Tolman, E. Bill, L. Gagliardi, C. C. Lu, Inorg. Chem., 2015, 54, 7579-7592.

26 (a) M. Carrasco, N. Curado, E. Álvarez, C. Maya, R. Peloso, M. L. Poveda, A. Rodríguez, E. Ruiz, S. Álvarez, E. Carmona, Chem. - A Eur. J., 2014, 20, 6092-6102; (b) M. Carrasco, N. Curado, C. Maya, R. Peloso, A. Rodríguez, E. Ruiz, S. Alvarez, E. Carmona, Angew. Chem. Int. Ed., 2013, 52, 3227-3231.

27 (a) P. Siega, L. Randaccio, P. A. Marzilli, L. G. Marzilli, Inorg. Chem., 2006, 45, 3359-68; (b) C. A. Tolman, Chem. Rev. 1977, 331-348

28 S. E. Kegley, A. R. Pinhas, in Problems and Solutions in Organometallic Chemistry, Oxford University Press, 1986.

29 Y.-C. Tsai, Y.-M. Lin, J.-S. K. Yu, J.-K. Hwang, J. Am. Chem. Soc., 2006, 128, 13980-13981.

30 (a) T. G. Appleton, H. C. Clark, L. E. Manzer, Coord. Chem. Rev., 1973, 10, 335-422; (b) F. R. Hartley, Chem. Soc. Rev., 1973, 2, 163-179; (c) L. J. Manojlovic-Muir, K. W. Muir, Inorg. Chim. Acta, 1974, 10, 47-49; (d) E. M. Shustorovich, M. A. 
Porai-Koshits, Y. A. Buslaev, Coord. Chem. Rev., 1974, 17, 198; (e) T. G. Appleton, M. A. Bennett, Inorg. Chem., 1978, 17, 738-747; (f) K. I. Purcell, J. C. Kotz, in Inorganic Chemistry, W. B. Saunders, Co. Philadelphia, 1977, Chapter 13; (g) J. C. Toledo, B. d. S. L. Neto, D. W. Franco, Coord. Chem. Rev., 2005, 249, 419-431; (h) J. Zhu, Z. Lin, T. B. Marder, Inorg. Chem., 2005, 44, 9384-9390; (i) S. G. Koller, R. Martín-Romo, J. S. Melero, V. P. Colquhoun, D. Schildbach, C. Strohmann, F. Villafañe, Organometallics, 2014, 33, 7329-7332.

31 (a) M. A. Ortuño, P. Vidossich, G. Ujaque, S. Conejero, A. Lledós, Dalton Trans., 2013, 42, 12165-12172; (b) M. Etienne, J. E. MacGrady, F. Maseras, Coord. Chem. Rev., 2009, 253, 635-646.

32 K. A. Connors, in Chemical Kinetics. The Study of Reaction Rates in Solution, John Wiley \& Sons, Inc., 1990.

33 Unpublished work from these laboratories.

34 S. Horvath, S. I. Gorelsky, S. Gambarotta, I. Korobkov, J. Am. Chem. Soc., 2008, 47, 9937-9940.

35 A. Noor, S. Schwarz, R. Kempe, Organometallics, 2015, 34, 2122-2125.

36 B. E. Bursten, R. H. Cayton, Organometallics, 1986, 47, 10511053.

37 J. R. Torkelson, F. H. Antwi-Nsiah, R. McDonald, M. Cowie, J. G. Pruis, K. J. Jalkanen, R. L. DeKock, J. Am. Chem. Soc., 1999, 121, 3666-3683.

38 1. M. J. Frisch et al. (2009). Gaussian 09 (Revision A.1) Wallingford, $\mathrm{CT}$.

392 A. D. Becke, J. Chem. Phys., 1993, 98, 5648-56752.

403 A. Schäfer, C. Huber, R. Ahlrichs, J. Chem. Phys., 1994, 100, 5829-5835.

414 R. Ahlrichs, K. May, Phys. Chem. Chem. Phys., 2000, 2, 943-945. 